\title{
The impact of house prices on consumption in the UK: a new perspective
}

Article

Accepted Version

Burrows, V. (2018) The impact of house prices on consumption in the UK: a new perspective. Economica, 85 (337). pp. 92-123. ISSN 1468-0335 doi:

https://doi.org/10.1111/ecca.12237 Available at https://centaur.reading.ac.uk/66646/

It is advisable to refer to the publisher's version if you intend to cite from the work. See Guidance on citing.

To link to this article DOI: http://dx.doi.org/10.1111/ecca.12237

Publisher: Wiley-Blackwell

All outputs in CentAUR are protected by Intellectual Property Rights law, including copyright law. Copyright and IPR is retained by the creators or other copyright holders. Terms and conditions for use of this material are defined in the End User Agreement.

\section{www.reading.ac.uk/centaur}

\section{CentAUR}

Central Archive at the University of Reading

Reading's research outputs online 


\title{
The impact of house prices on consumption in the UK: a new
}

\author{
perspective
}

Vivien Burrows *†

August 22, 2016

\begin{abstract}
This paper proposes an alternative approach to the question of how house prices influence household consumption by focusing on the impact of changes in housing wealth on household mortgage borrowing and saving. Household-level data are used to derive a measure of expected and unexpected changes to house prices in a first stage, which are then incorporated into a recursive bivariate probit model of the decision to withdraw housing equity and save. Both expected and unexpected changes in house prices have a positive impact on the propensity to withdraw equity, however this is mainly for younger households. Changes in housing wealth have no direct impact on household saving, either for young or older homeowners, although they do have an important indirect impact, since they increase the likelihood the household will withdraw equity, which in turn has a negative impact on household saving. (JEL:D91, E21, R31)

Keywords: mortgage equity withdrawal, household saving, expected and unexpected house price

changes, bivariate probit model
\end{abstract}

\begin{abstract}
*Department of Economics, University of Reading, Reading, UK. e-mail: v.e.burrows@reading.ac.uk.
${ }^{\dagger}$ This paper is based on research I carried out as part of my PhD at the University of York, which was funded by the Economic and Social Research Council. I would like to thank my thesis supervisor at York, Peter Simmons, the examiners for my PhD viva, James Banks and Jo Swaffield, and my current research mentor, Geoff Meen. Special thanks go to two anonymous referees and two editors of this journal for very helpful suggestions. I would also like to thank the participants at the EEA 2013 Conference in Gothenburg, the Finance and Economics Conference 2013 in Frankfurt, the ENHR workshop in Vienna, and at presentations at the universities of Reading and York for helpful comments and suggestions. The data used in this publication were made available through the ESRC Data Archive. The data were originally collected by the ESRC Research Centre on Micro-social Change at the University of Essex (now incorporated within the Institute for Social and Economic Research). Neither the original collectors of the data nor the Archive bear any responsibility for the analyses or interpretations presented here.
\end{abstract}




\section{Introduction}

The question of whether and how house prices influence household consumption is one which has been widely debated within the economics literature. Among the more recent papers focusing on this issue, some have found evidence that consumption responds to changes in housing wealth, either through a direct wealth effect, whereby households adjust their lifetime consumption in response to changes in their housing wealth (Carroll et al., 2011; Campbell and Cocco, 2007; Case et al., 2005), or through a collateral effect, with increases in housing wealth facilitating access to borrowing (Browning et al., 2013; Campbell and Cocco, 2007; Disney et al., 2010a; Disney et al., 2010b; Iacoviello, 2004). However others have argued that in fact the observed correlation between consumption and house prices is driven by common factors, such as changes to expected future income (Attanasio et al., 2009). Most of the applied microeconomic work in this area has focused on estimating models of household consumption which incorporate housing wealth.

This paper proposes an alternative approach to this question by focusing on the impact of changes in housing wealth on household borrowing and saving simultaneously. For homeowners, if house prices do have an impact on consumption, then households should respond to increases in their housing wealth by either decreasing their saving or by borrowing more. The focus here is on secured borrowing, where households borrow against their housing equity, rather than unsecured borrowing. This form of borrowing accounts for a larger proportion of household debt, and is generally available on more favourable terms, which suggests a natural ordering of borrowing, where the majority of household debt is secured on the property (Disney et al., 2010a). The question of whether increases in house prices impact on consumption primarily by increasing borrowing or decreasing household saving is important given the significant volatility of house prices in the UK, since the former leaves households more exposed in the event of a fall in house 
prices.

Existing studies of the mortgage equity withdrawal decision have focused on the role of lifecycle or consumption-smoothing motives (Benito, 2009; Ebner, 2010; Hurst and Stafford, 2004) and financial motives, such as remortgaging to take advantage of lower interest rates (Benito, 2009; Canner et al., 2002; Ebner, 2010). The impact of house prices is either not explicitly considered (Hurst and Stafford, 2004), or is based on a measure of realised house price gains (Disney et al., 2010a; Ebner, 2010; Benito, 2009; Canner et al., 2002). Having equity in the home is necessary to be able to access it, but if households are forward-looking then it is not just actual changes in house prices that should matter, but also household expectations about future house price movements.

The importance of considering house price expectations has been widely recognised in the literature exploring the impact of house prices on consumption. In a paper which is similar in spirit to the work carried out here, Disney et al. (2010b) analyse the impact of house price shocks on household saving for a sample of UK households, and find a small but significant impact on household saving for homeowners. Income expectations have been identified as a potential confounding factor behind the rise in both house prices and consumption (Attanasio et al., 2009; Attanasio and Weber, 1994), and Disney et al. (2010b) control for these using a measure of households' subjective financial expectations. An alternative approach, adopted by Browning et al. (2013), has been to derive a measure of expected and unexpected changes in income directly from the data.

Of course, household borrowing and saving decisions are not independent. Hurst and Stafford (2004) find that households with low levels of liquid assets are significantly more likely to withdraw housing equity in response to negative financial shocks. However, borrowing may itself strengthen the precautionary demand for saving, or households may use the equity withdrawn to invest in financial assets, particularly if the expected rate of return exceeds the interest rate on 
mortgage debt. It is, therefore, important to allow for the possibility of feedback effects between borrowing and saving.

Data from the British Household Panel Survey (BHPS) covering the period from 1995 to 2007 is used to estimate a recursive bivariate probit model of household mortgage equity withdrawal and saving, which allows for borrowing to have an impact on current saving decisions. The paper separately explores the impact of realised house price gains and expected and unexpected changes in house prices, controlling for household income expectations. In a first stage, household-level data are used to derive a measure of expected and unexpected changes to house prices and income, in a similar vein to Browning et al. (2013) and Disney et al. (2010b) in their analyses of the impact of house prices on consumption. These are then incorporated into the bivariate model of the decision to withdraw housing equity and save, which is estimated for the sample as a whole, as well as separately for a sub-sample of younger and older homeowners. Brown et al. (2008) analyse the household decision to save and borrow jointly using US data, although their focus is on unsecured debt and they do not consider the impact of house prices explicitly.

The results of the bivariate probit model suggest these decisions are not independent. Realised house price gains and expected and unexpected changes in house prices have a positive and significant impact on the probability of withdrawing equity, but this is mainly for younger households. Disney et al. (2010a) also find that changes in house prices have an impact on mortgage equity withdrawal for households in the UK, although this is only significant for households with high levels of unsecured debt, which suggests that increasing house prices boost consumption through a collateral effect, allowing previously constrained households to increase their borrowing and substitute secured for unsecured debt.

Neither realised changes in house prices nor house price shocks are found to have a direct impact on household saving, which is at odds with the findings in Disney et al. (2010b). However their measure of saving explicitly includes retirement saving and they use county-level house price 
data to derive their measure of house price shocks. The results in this paper do, however, suggest an important indirect effect of house price shocks on saving, since they increase the likelihood the household will withdraw equity, which is found to have a negative impact on household saving. The magnitude of the impact of house price shocks is significantly larger than the impact of realised house price gains.

Although there is some debate about whether changes in house prices can have a significant impact on aggregate consumption (Buiter, 2008), these findings do have important implications given the fluctuations in house prices in the UK observed in recent years and the fact that housing is the largest asset in most household portfolios. They also go some way towards explaining the sharp increase in housing equity withdrawal and decline in household saving observed in the UK from the end of the 1990s until the onset of the recent financial crisis, when house prices were rising.

The next section describes the theoretical background to the model estimated in this paper. Section 3 provides an overview of the data used and Section 4 outlines the model, including the processes specified to model housing wealth and household income. The estimation results are presented in Section 5 and Section 6 concludes.

\section{Theoretical background}

The starting point adopted for exploring the impact of house prices on consumption is a modified version of the lifecycle model of consumption and saving with rational expectations, where households face uncertainty about their future income and housing wealth. In each period households choose how much to save and how much to borrow, which jointly determine their level of consumption. In this paper we abstract from the issue of unsecured borrowing and focus only on secured borrowing, so the maximum amount a household can borrow is tied to the value of 
their housing wealth, although it will also depend on their level of income.

The model treats saving and new mortgage borrowing as two separate, yet interrelated, decisions. In a world of certainty, with perfect capital markets, where the interest rates on saving and borrowing are equal and individuals are free to increase or decrease their outstanding mortgage debt, the decisions to save and borrow would be one and the same. However, in practice, differential interest rates, potential constraints on borrowing and uncertainty surrounding future income and house values provide households with different motivations for saving and borrowing.

The literature exploring the impact of house prices on consumption has focused on two main channels through which increases in house prices may lead to increases in consumption: the wealth channel and the collateral channel (Browning et al., 2013; Campbell and Cocco, 2007; Carroll et al., 2011; Disney et al., 2010b). Under the former, increases in house prices increase household wealth, shifting the intertemporal budget constraint outwards and allowing households to adjust their consumption. Within a lifecycle framework, households are assumed to make their consumption plans based on the expected evolution of lifetime wealth, constrained by their current resources, therefore only unexpected changes in house prices should have an impact on consumption. The collateral channel is based on the fact that increases in house prices relax borrowing constraints, allowing previously constrained households to increase their consumption by borrowing against their housing equity. In this case, consumption may respond to expected changes in house prices.

The existence of pure wealth effects is subject to debate. Housing is both a consumption good and an investment good (Henderson and Ioannides, 1983), and all households must consume some level of housing. Assuming the housing market is in equilibrium, total consumption of housing services must equal the stock of available housing, which implies that the household sector as a whole cannot substitute out of housing to finance additional non-housing consumption, and therefore there can be no aggregate wealth effects of house prices on consumption. This point 
has been demonstrated by Buiter (2008), although it holds only for changes in house prices which are due to changes in their fundamental value; a change in housing wealth may still affect consumption if it is due to a change in the speculative bubble component of house prices. There may also be individual-level wealth effects, as a change in the fundamental value of house prices redistributes wealth from those "long" in housing, who are planning to reduce their consumption of housing in the future, to those "short" in housing ${ }^{1}$, and the impact of these redistributional changes on aggregate consumption is unclear (Buiter, 2008).

In the context of the model adopted in this paper, households may respond to changes in house prices by either adjusting their mortgage borrowing or their saving. If the wealth channel is important, then unexpected increases in house prices should in general have a negative impact on household saving. Saving should not respond to anticipated changes in housing wealth if households are forward-looking (Disney et al., 2010b). However, if borrowing responds to unexpected changes in house prices this may signal both wealth or collateral effects. Unfortunately it is not possible to disentangle these two effects in this paper. Distinguishing between the two would require knowledge of the exact timing of the equity withdrawal decision and the house value to which the decision was tied. Borrowing may also respond to anticipated changes in housing wealth if the household previously faced constraints on borrowing.

The direction of the impact of increases in housing wealth on household saving/borrowing will depend on households' planned housing consumption, in particular whether households are planning to upsize or downsize in the future (Disney et al., 2010a; Disney et al., 2010b; Attanasio et al., 2009). Younger households planning to trade up in the future, to meet the needs of a growing family size, will want to accumulate equity in their home and therefore may be less likely to respond to increases in house prices, particularly if they live in areas with significant house price volatility (Banks et al., 2010). These households may actually increase saving in response to house price shocks, due to the down-payment constraint (Engelhardt, 1996). 
Whether households respond to changes in house prices primarily by adjusting their borrowing or saving will depend on what stage of the lifecycle they are at. Borrowing involves a fixed cost and any new borrowing has to be repaid, therefore we would expect younger households with a longer working life ahead of them, and who are less likely to have accumulated significant financial assets, to be more likely to respond to increases in house prices by increasing their borrowing rather than reducing saving. Younger households are also more likely to be borrowing constrained since they will have had less time to accumulate equity in their home. If increases in house prices impact on consumption primarily by unbinding these constraints, then we would expect younger households to be more likely to respond to changes in house prices by increasing their mortgage borrowing. While older households will typically have accumulated more equity in their homes, they may be more likely to respond to house price shocks by adjusting their savings, particularly if their housing wealth is used as insurance against retirement contingencies or if housing bequest motives are important.

Households may also respond to changes in house prices by adjusting both borrowing and saving. There are two main reasons why they might do this: (1) borrowing may be required to finance some large expenditure, however households may recognise the risks associated with withdrawing equity, which will therefore induce precautionary saving; (2) households may remortgage to take advantage of lower mortgage interest rates, and withdraw some housing equity in the process, or they may withdraw equity to invest in financial assets where the rate of return is higher than the mortgage interest rate. Angelini and Simmons (2005) find that the difference between the mortgage and saving interest rates plays an important role in driving the refinancing decision; households will pay the fixed cost of remortgaging when this difference is sufficient to cover the transaction cost of remortgaging. In both cases, the impact of house price shocks on final consumption will be reduced.

Income expectations have been identified as a potential confounding factor behind the rise 
in both house prices and consumption (Attanasio et al., 2009; Attanasio and Weber, 1994), and therefore any model of household consumption and saving with housing wealth should take these into account. Under the assumptions of the traditional lifecycle/permanent income hypothesis, if households expect their incomes to rise, they should bring consumption forward, financed either by borrowing or dissaving (Deaton, 1992). Within the same framework, the impact of income shocks will depend on whether these shocks are perceived to be permanent or transitory, and whether buffer-stock saving motives are important (Carroll, 2009; Deaton, 1991). If consumers are both impatient and prudent, then faced with income uncertainty, precautionary motives may interact with borrowing constraints to provide an additional motive for holding assets (Deaton, 1991).

\section{Mortgage equity withdrawal and saving in the BHPS}

This paper uses data from the British Household Panel Survey (BHPS), an annual survey of around 5500 households in the United Kingdom which has been running since 1991. The sample used covers the years between 1995 and 2007, a period of rising house prices and relative economic prosperity, and includes owner-occupier households only ${ }^{2}$. The final sample is an unbalanced panel with 5612 households and a total of 32869 observations.

In each year of the survey households are asked whether they have increased their mortgage borrowing by taking out an additional mortgage and if so how much was borrowed, which is used as a measure of active mortgage equity withdrawal ${ }^{3}$. The terms mortgage equity withdrawal and remortgaging are used interchangeably in this paper, and both imply that the household has increased the loan amount outstanding. Households have other mechanisms available for accessing their housing equity, for example by downtrading or overmortgaging, but Greenspan and Kennedy (2008) suggest that active mortgage equity withdrawal is more closely linked to 
household spending.

Detailed information on the different types of assets held by households was only collected in three of the years covered by the sample. However households are asked in each year whether they save regularly from their current income and this variable provides the measure of saving used in this paper ${ }^{4}$. A separate question in the survey asks explicitly about contributions to private pension schemes, therefore the measure of saving used here should largely abstract from retirement saving. While information on mortgage borrowing is collected at the household level, information on regular saving is collected at the individual level, so the saving information is aggregated across the household reference person and, where applicable, their spouse/partner. A household is counted as saving regularly if either the household reference person or spouse save on a regular basis.

During the sample period there were 1781 cases of households increasing their mortgage borrowing, which represents around $8 \%$ of all households with positive mortgage debt. The average real value of the additional borrowing was $£ 21,721$, which was significantly higher than the median value, $£ 13,265$. Roughly $61 \%$ of survey respondents save on a regular basis and the average amount saved each year is just over $£ 3,190$.

The proportion of households withdrawing equity tended to increase over the sample period, as did the average level of equity withdrawn (Figure 1), which is consistent with the trend in rising house prices between 1995 and 2007. The proportion of households saving fell quite dramatically over the period, although the average amount saved increased (Figure 2). 

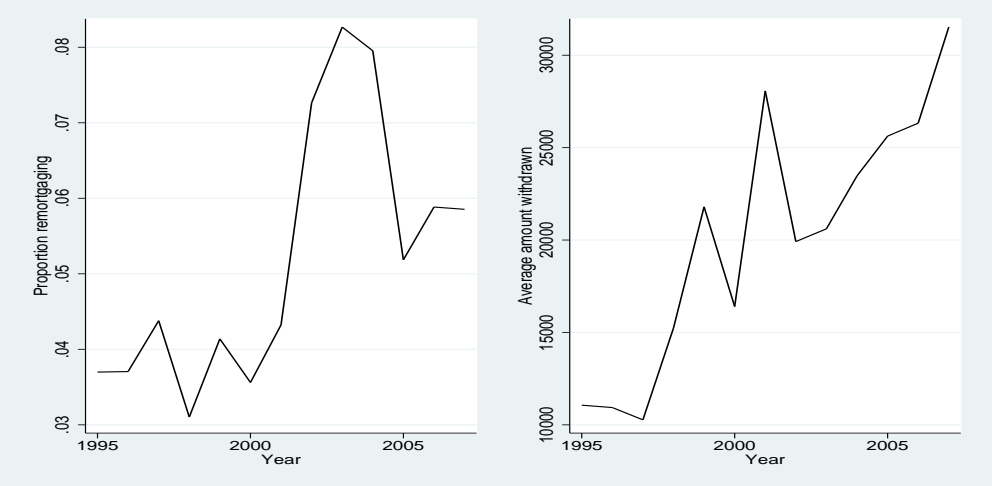

Figure 1: Equity withdrawal and average amounts withdrawn (real)
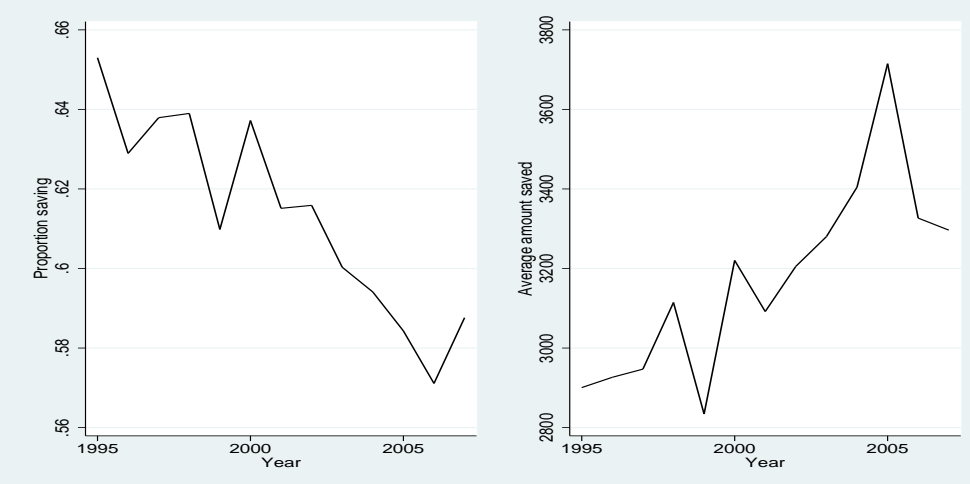

Figure 2: Household saving and average annual amounts saved (real)

Both equity withdrawal and saving are closely related to the lifecycle (Figure 3). The incidence of equity withdrawal increases with age, peaking at around age 40, although the average amounts withdrawn fluctuate quite significantly. The number of households saving regularly and the average amount saved has the typical hump-shaped profile. 


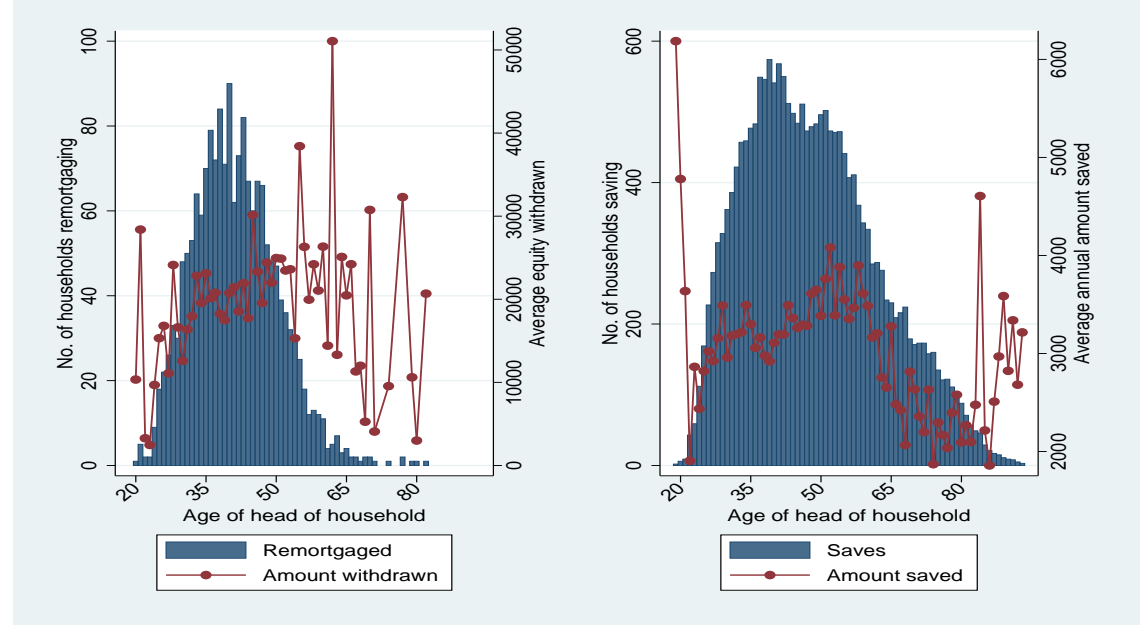

Figure 3: Equity withdrawal and saving over the lifecycle

Mortgage equity withdrawal is also closely associated with certain key life events, such as having children or divorce (see Table 8 in the Appendix). Households with young children are more than twice as likely to withdraw housing equity than households without children, and this is true for both couples and single-parent households. Divorced or separated heads of household are also significantly more likely to withdraw housing equity than single or cohabiting households without children.

In order to gain a better understanding of how these two decisions vary over the lifecycle, and therefore how different households are likely to respond to rising house prices, Table 1 presents some descriptive statistics, where households have been divided into four categories based on whether they withdrew equity in the past year or not $(M=1$ or $M=0)$ and whether they save regularly from their current income or not $(S=1$ or $S=0)$. Households that have not withdrawn equity recently may still have outstanding mortgage debt to pay. 
Table 1: Summary Statistics

\begin{tabular}{|c|c|c|c|c|c|}
\hline & $\mathrm{M}=1$ & $M=1$ & $M=0$ & $\mathrm{M}=0$ & Full \\
\hline & $\mathrm{S}=1$ & $\mathrm{~S}=0$ & $\mathrm{~S}=1$ & $\mathrm{~S}=0$ & sample \\
\hline & (1) & $(2)$ & $(3)$ & $(4)$ & $(5)$ \\
\hline house value & 163532 & 162053 & 150471 & 146420 & 149657 \\
\hline no. of rooms & 5.259 & 5.032 & 5.004 & 4.842 & 4.953 \\
\hline lagged home equity & 82942 & 79710 & 105885 & 108503 & 105474 \\
\hline monthly mortgage costs & 526 & 503 & 393 & 377 & 398 \\
\hline total annual household income & 42960 & 36352 & 38210 & 29658 & 35178 \\
\hline annual household labour income & 39584 & 32580 & 31631 & 21472 & 28173 \\
\hline household investment income & 957 & 727 & 1625 & 1428 & 1511 \\
\hline stock of assets ${ }^{\mathrm{a}}$ & 12927 & 8674 & 26090 & 21530 & 23607 \\
\hline annual amount saved & 2627 & - & 3222 & - & 3190 \\
\hline owes money $^{\mathrm{b}}$ & 0.612 & 0.617 & 0.395 & 0.361 & 0.392 \\
\hline age & 41 & 42 & 49 & 52 & 50 \\
\hline number of children & 0.971 & 1.075 & 0.528 & 0.567 & 0.569 \\
\hline married/ couple & 0.858 & 0.738 & 0.820 & 0.716 & 0.781 \\
\hline retired & 0.008 & 0.014 & 0.172 & 0.292 & 0.207 \\
\hline household size & 3.143 & 3.201 & 2.655 & 2.660 & 2.684 \\
\hline Observations & 1059 & 722 & 19004 & 12084 & 32869 \\
\hline
\end{tabular}

The table reports sample means and sample proportions for dummy variables. All monetary variables are in real terms. a Information on households' financial assets is only collected in three of the years - 1995, 2000 and 2005 - and the average across these three years for all households is reported here. The average includes imputed data. $\quad{ }^{b}$ Households are asked whether they currently owe money (excluding mortgage or other housing loans), for example on hire purchase loans, personal loans or credit cards, but this information is only collected in three of the waves used here. 
Households that withdrew equity (columns (1) and (2)) live in homes which are on average more expensive, but not necessarily larger. They are on average younger, have higher average labour income, lower levels of lagged home equity - that is before any increase in mortgage borrowing - and financial assets, which suggests these households are at an earlier stage in the lifecycle, having had less time to accumulate both financial and housing wealth. They are also more likely to have other forms of debt. The household size, number of children and size of the property can be used as proxies for the housing ladder (Banks et al., 2010), and the higher average values for households that withdrew equity suggests these households have reached the 'peak' of the housing ladder and are unlikely to want to upsize in the future.

There are no significant age differences between households that do not withdraw housing equity (columns (3) and (4)). However those that do not save on a regular basis have lower incomes on average, and particularly a lower average labour income, lower holdings of financial assets and are more likely to be retired. The smaller average household size for both these categories of household is not matched by a significantly smaller average property size, which suggests these households could potentially downsize in the future and use this a means of releasing housing equity.

Just under sixty per cent of households who remortgaged also save on a regular basis, although the Pearson chi square test of independence fails to reject the null that the remortgaging and saving variables are independent ${ }^{5}$. The discussion in Section 2 highlighted two main reasons why households may save and borrow simultaneously: borrowing may be required to finance some large expenditure, but the risks associated with borrowing may encourage households to increase their saving; or households may use some of the equity withdrawn to invest in financial assets and thereby rebalance their portfolios. The significance of the second motive is difficult to assess with the data available - detailed information on financial assets is only collected in three of the years and households are not asked whether any of the additional borrowing was used to pay off debts 
or reinvest. However the evidence suggests that borrowing-induced precautionary saving may be important: the majority of households report using the equity withdrawn to finance home extension or home improvement work (Table 2) and the average amount of equity withdrawn by these households $(£ 20,599)$ is greater than their average holdings of financial assets $(£ 13,246)$.

Households who remortgaged and do not save regularly, are not significantly older than those who save, however they do have a marginally lower level of home equity and lower financial assets. They are also more likely to use the equity withdrawn to finance other non-specified expenditures (Table 2). This suggests these households would benefit the most from any unexpected increase in house prices.

Table 2: Reason for withdrawing equity

\begin{tabular}{lcc}
\hline Reason & Saves regularly & Doesn't save regularly \\
& $\%$ & $\%$ \\
\hline home extension & 22.02 & 16.90 \\
home improvements & 49.53 & 45.29 \\
car purchase & 8.13 & 8.03 \\
other consumer goods & 4.44 & 6.23 \\
other expenditure & 32.42 & 39.75 \\
\hline \hline
\end{tabular}

Sample size: 1058 households who save regularly and 722 households that do not save regularly. Households may provide more than one reason. 


\section{Empirical model specification}

\subsection{Bivariate model of MEW and saving}

The mortgage equity withdrawal and household saving decisions are modelled jointly. The potential for borrowing to strengthen the precautionary saving motive or be used to invest in financial assets suggests a recursive simultaneous equation model, where the household's decision to withdraw housing equity may influence their decision to save.

Household saving behaviour could also be expected to influence the decision to withdraw housing equity: if households are less likely to save, their stock of financial assets will be lower, which strengthens the motives for equity withdrawal (Hurst and Stafford, 2004). However in the present paper the variable used to capture equity withdrawal measures whether a household withdrew housing equity between period $t-1$ and $t$, whereas the variable measuring household saving behaviour refers to saving in period $t$, and it seems unlikely that future saving behaviour would determine past borrowing behaviour. To control for the impact of financial assets on the equity withdrawal decision, the model includes the stock of household financial assets as an additional control.

The variables used to capture households' mortgage equity withdrawal and saving decisions are binary, as described in Section 3, but the model is based on a latent variable specification, where $M_{i t}^{*}$ and $S_{i t}^{*}$ represent household $i$ 's unobserved propensity to withdraw equity and save in period $t$ respectively. The model is outlined in equations (1) and (2) below:

$$
\begin{aligned}
M_{i t}^{*} & =\beta_{0}+\beta_{1} E\left(\Delta \pi_{i t}\right)+\beta_{2} \epsilon_{i t}^{\pi}+\beta_{3} E\left(\Delta y_{i t}\right)+\beta_{4} \epsilon_{i t}^{y}+\beta_{5} A_{i} \\
& +\beta_{6} m_{i t-1}+\beta_{7} \sigma_{i t}^{y}+\beta_{8} \sigma_{r t}^{\pi}+\beta_{9} Z_{i t}+\delta_{t}+u_{i t}^{M}
\end{aligned}
$$




$$
\begin{aligned}
& M_{i t}=1 \text { if } \quad M_{i t}^{*}>0 \\
& M_{i t}=0 \text { otherwise }
\end{aligned}
$$

$$
\begin{aligned}
S_{i t}^{*} & =\gamma_{0}+\gamma_{1} E\left(\Delta \pi_{i t}\right)+\gamma_{2} \epsilon_{i t}^{\pi}+\gamma_{3} E\left(\Delta y_{i t}\right)+\gamma_{4} \epsilon_{i t}^{y}+\gamma_{5} A_{i} \\
& +\gamma_{6} m_{i t-1}+\gamma 7 M_{i t}+\gamma_{8} \sigma_{i t}^{y}+\gamma_{9} \sigma_{r t}^{\pi}+\gamma_{10} Z_{i t}+\delta_{t}+u_{i t}^{S}
\end{aligned}
$$

$$
\begin{array}{ll}
S_{i t}=1 & \text { if } \quad S_{i t}^{*}>0 \\
S_{i t}=0 & \text { otherwise }
\end{array}
$$

The household's expected change in house prices from period $t-1$ to period $t$ is captured by $E\left(\Delta \pi_{i t}\right)$, and $\epsilon_{i t}^{\pi}$ captures the unexpected change or shock to house prices in period $t . E\left(\Delta y_{i t}\right)$ denotes the household's expected change in income between period $t-1$ and $t$, and $\epsilon_{i t}^{y}$ captures unexpected income changes in period $t$. The potential for house prices and consumption to be jointly driven by income expectations (Attanasio et al., 2009; Attanasio and Weber, 1994) suggests it is important to control for these in the estimation. Expected changes in house prices and income are derived from a first stage estimation of processes for these variables as explained in section 4.2 below, and the unexpected shocks to housing wealth and income are measured as the residuals of these first stage regressions, as in Browning et al. (2013), and Disney et al. (2010b).

Given that households with low levels of liquid assets are significantly more likely to withdraw housing equity, particularly in response to negative financial shocks (Hurst and Stafford, 2004), the $\log$ of the stock of assets owned by the household, $A_{i}$, is included as a proxy for these liquidity 
constraints in equation (1), as in Benito $(2009)^{6}$.

Households may remortgage to take advantage of low interest rates and reduce their mortgage repayments (Hurst and Stafford, 2004; Canner et al., 2002). Benito (2009) captures these financial efficiency motives for remortgaging using the lagged level of outstanding mortgage debt, since a higher level of debt would imply higher potential interest savings from remortgaging. The $\log$ of outstanding mortgage debt in the previous period, $m_{i t-1}$, is included in both the equity withdrawal and saving equations, to capture both these financial efficiency motives for withdrawing equity and the fact that borrowing may strengthen the precautionary saving motive. The binary outcome variable that captures whether household $i$ withdrew equity since the previous year, $M_{i t}$, is also included in the saving equation.

The two terms, $\sigma_{i t}^{y}$ and $\sigma_{r t}^{\pi}$, capture income and house price volatility respectively ${ }^{7}$. If the precautionary saving motive is important, then the variance of income will have a significant impact on saving and borrowing behaviour. Greater house price volatility should have a negative impact on the propensity to remortgage (Banks et al., 2010), while providing a further incentive for households to save.

The model includes a vector of household and mortgage characteristics, $Z_{i t}$, which include the age and age squared of the head of household; the number of children; dummy variables for the employment status and level of education of the head of household; whether the head of household got married or divorced in the previous year, as a measure of non-financial shocks (as in Benito, 2009); a dummy variable for whether the household has an endowment mortgage; and whether the household has moved in the previous year. Housing needs vary over the lifecycle and the demographic variables included in the model are intended to control for this (Disney et al., 2010b).

The likely impact of endowment mortgages on equity withdrawal and saving is unclear (Benito, 2009). These interest-only mortgages expose the household to greater investment risk, which 
may reduce the propensity to withdraw equity (and increase the propensity to save), or they may signal a greater tolerance towards risk and therefore a greater willingness to withdraw equity and a weakening of the precautionary saving motive.

Moving house is an important means for releasing equity ${ }^{8}$, and therefore households that move may be less likely to withdraw equity by remortgaging. Disney et al. (2002), in an analysis of saving among elderly households in the UK, find significant differences in responses to house price changes between households that move and those that do not. It is therefore important to control for whether the household moves in the estimation for both the mortgage debt and saving equations ${ }^{9}$.

Year dummies, $\delta_{t}$, are used as proxies for interest rate uncertainty, given that households face different interest rates for borrowing and saving. Aggregate interest rate data are also used as a robustness check.

The two equations for equity withdrawal and saving are estimated jointly using a bivariate probit model. If the two error terms, $u_{i t}^{M}$ and $u_{i t}^{S}$, are correlated, then a bivariate approach will produce more efficient estimates. The conditional correlation parameter $\rho$ will give an indication of the degree of interdependence between the variables. Model specification is particularly important in this context, since any variables incorrectly omitted from the model will automatically result in a non-zero estimate of $\rho$.

Identification of the standard (non-recursive) bivariate probit model does not require exclusion restrictions and allows for the variables determining $M_{i t}$ and $S_{i t}$ to be the same or different. Identification of the recursive model specified above relies on the fact that while $M_{i t}$ may have an impact on the latent variable $S_{i t}^{*}$, the reverse is not the case. The model can be consistently and efficiently estimated as a bivariate probit model by full information maximum likelihood (Greene, 2003; Greene, 1998). 


\subsection{The house price and income processes}

Estimating the model outlined above requires information on households' expectations of their future income and housing wealth, which are not directly collected in the BHPS ${ }^{10}$. Therefore, separate models for income and house prices are specified and estimated in a first stage, in order to derive estimates of the expected and unexpected changes to these variables.

There has been a growing interest in modelling stochastic processes for house prices, particularly in micro-level studies focusing on the impact of house prices on consumption, however the majority of these studies rely on aggregate regional or county-level house price data (Browning et al., 2013; Disney et al., 2010a; Attanasio et al., 2009; Campbell and Cocco, 2007). With the exception of the paper by Browning et al. (2013), the properties of the house price series are not really explored in depth. These authors use Danish municipal-level house price data to estimate a first-order autoregressive model with unobserved municipality-level fixed effects, and explicitly test for nonstationarity in house prices. This paper adopts a similar approach, but using a more disaggregated measure of house values, namely households' self-reported estimate of the value of their home.

Households are assumed to base their expectations of future house price movements on the current (log) real self-reported value of their property, $\pi_{i t-1}$, and a vector of household characteristics, $x_{i, t-1}$ :

$$
\pi_{i t}=\alpha^{\pi} \pi_{i, t-1}+\phi x_{i, t-1}+\delta_{t}+\eta_{i}+\epsilon_{i t}^{\pi}
$$

The household characteristics include the age of the head of household, the number of years since the household last moved and a measure of the size of the property. This last variable will capture any structural improvement work to the property. Time dummies, $\delta_{t}$, and an unobserved household-specific fixed effect, $\eta_{i}$, are included in the model, and the error term $\epsilon_{i t}^{\pi}$ 
follows a first-order moving-average process. To capture any regional differences in the evolution of house prices, the house price equation is estimated separately for three region groups.

The self-reported house values are potentially more informative than aggregate house price data as a measure of households' house price expectations, since they capture households' perceived housing wealth. Given the measure of housing wealth used, measurement error is a potential problem, however evidence from Redwood and Tudela (2004) suggests that households' perception of their house value in the BHPS is in fact fairly accurate, when compared to the aggregate data, but it will capture a lot more variability across households.

Disney et al. (2010b) argue that using this measure of housing wealth may be problematic, since it it will also reflect expenditure on home improvements and moving behaviour, which may be correlated with household saving. Both the specification above and the model of household saving and remortgaging behaviour control for whether the household has recently moved, however information on home improvement work is only available in the BHPS if the work was financed through additional mortgage borrowing. Substantial home improvement work would arguably be more likely to be financed through a remortgage loan or accumulated financial wealth so the impact on day-to-day saving may be expected to be small. Nonetheless, a dummy variable controlling for whether the remortgage loan was primarily used to finance home improvement work was included in some of the specifications below. Although there are risks associated with using this measure of housing wealth, there are also potential benefits, as perceived gains in housing wealth may be more important in driving individual saving behaviour than actual gains (Engelhardt, 1996).

Households use information available at period $t-1$ when forming their expectations of their house value in period $t$, and their expectations of changes in house prices can be directly computed as, 


$$
E_{t-1}\left(\Delta \pi_{i t}\right)=E_{t-1}\left(\pi_{i t}\right)-\pi_{i, t-1}
$$

Shocks to housing wealth are captured by the residuals of this first stage regression.

There is a vast literature on modelling income processes, and more recently interest has shifted to estimating dynamic models for income ${ }^{11}$. This paper specifies a first-order autoregressive process for income, as in Browning et al. (2013), where log real annual income for household $i$ in period $t, y_{i t}$, is regressed on lagged log income, a vector of household characteristics, $z_{i, t-1}$, and year dummies, $\delta_{t}$ :

$$
y_{i t}=\alpha^{y} y_{i, t-1}+\lambda z_{i, t-1}+\delta_{t}+\eta_{i}+\epsilon_{i t}^{y}
$$

The measure of income used includes both labour and non-labour income, where non-labour income encompasses transfer, benefit and pension income. The vector of household characteristics includes the age and age squared of the head of household, the number of children and the number of people in employment in the household. The model also includes an unobserved householdspecific fixed effect, $\eta_{i}$, and the error term, $\epsilon_{i t}^{y}$, follows a first-order moving-average process. To capture the effects of education, the income equation is estimated separately for four education groups (Browning et al., 2013; Meghir and Pistaferri, 2004).

As with their house price expectations, households are assumed to use the information available in period $t-1$ when forming their expectations of income in period $t$, therefore household expectations of changes in income can be computed as,

$$
E_{t-1}\left(\Delta y_{i t}\right)=E_{t-1}\left(y_{i t}\right)-y_{i, t-1}
$$

Unexpected shocks to income are captured by the residuals of this first stage regression. 


\section{Results}

The model described above is estimated in two stages: in a first stage, the processes for house prices and income specified in section 4.2 are estimated in order to derive a measure of expected and unexpected changes to these variables; these are then incorporated into a bivariate probit model of household remortgaging and saving. The use of generated regressors in estimations is becoming increasing popular in microeconomic models. While in general this should not affect the consistency of coefficient estimates, it does have implications for the estimated standard errors (Wooldridge, 2002; Pagan, 1984).

The model was initially estimated using the full sample, controlling for the various household and housing characteristics described above, and these results are discussed in section 5.2. In order to assess whether there are any systematic differences in the equity withdrawal and saving behaviour of households at different stages of the lifecycle, the model was then estimated separately for households in two age groups: where the head of household is aged between 30 and 50, and where the head of household is aged over 50. These results are discussed in section 5.3.

\subsection{Estimating the models for house prices and income}

Households are assumed to base their expectations of future income and house price movements on the current level of income and house prices and a set of additional covariates, as specified in section 4.2. House prices are measured as the $\log$ of real self-reported house values given by respondents in the sample. The measure of income used is the log of annual real household income, which includes both labour and non-labour income of the household reference person and, where applicable, their spouse.

Given the dynamic specification adopted for both the income and house price processes, and to allow for unobserved household-specific fixed effects, these models were estimated using the 
System GMM estimator proposed by Arellano and Bover (1995) and Blundell and Bond (1998). This estimator has been shown to produce consistent and efficient estimates when the series are persistent but stationary, and is used by Browning et al. (2013) to estimate processes for income and house prices using Danish data.

Both the income and house prices series were tested for unit roots before estimation ${ }^{12}$. Several unit root tests for micro panels have been proposed, but Bond et al. (2005) find that tests based on least squares estimators perform quite well in general, even though these estimators are only consistent under the null hypothesis of a unit root. The house price series in particular is highly persistent, but the two tests employed both reject the null of a unit root for the house price and income series. This suggests that unexpected shocks to income or house prices are unlikely to have a lasting effect.

The asymptotic standard errors in the two-step GMM estimator have been shown to be too small, therefore the finite sample correction proposed by Windmeijer (2005) is used to compute the standard errors in the tables below.

\subsubsection{House price process}

The house price equation is estimated separately for three region groups: (1) North, which includes Scotland, the North West and East, Yorkshire and the Humberside; (2) Center, which includes East and West Midlands, and Wales; and (3) South, which includes the South East and West, London and East Anglia. The additional regressors included in the model are the age of the head of household, the number of years since the household last moved and the number of rooms in the property (excluding kitchens and bathrooms). The coefficient on lagged house prices is quite high for the North and Centre regions (0.898 and 0.900), but significantly lower in the South (0.447). 
Table 3: House prices - System GMM estimation by region group

\begin{tabular}{|c|c|c|c|}
\hline & $\begin{array}{l}\text { North } \\
(1)\end{array}$ & $\begin{array}{c}\text { Centre } \\
(2)\end{array}$ & $\begin{array}{l}\text { South } \\
(3)\end{array}$ \\
\hline$\pi_{i, t-1}$ & $\begin{array}{c}0.898^{* * *} \\
(0.034)\end{array}$ & $\begin{array}{c}0.900^{* * *} \\
(0.044)\end{array}$ & $\begin{array}{c}0.447^{*} \\
(0.269)\end{array}$ \\
\hline$a g e_{t-1}$ & $\begin{array}{c}-0.001^{* * *} \\
(0.000)\end{array}$ & $\begin{array}{l}-0.000 \\
(0.000)\end{array}$ & $\begin{array}{c}0.000 \\
(0.000)\end{array}$ \\
\hline yrs since last moved $_{t-1}$ & $\begin{array}{c}0.001 \\
(0.001)\end{array}$ & $\begin{array}{l}-0.002 \\
(0.002)\end{array}$ & $\begin{array}{c}-0.004 \\
(0.004)\end{array}$ \\
\hline no. of rooms rom $_{t-1}$ & $\begin{array}{c}0.044^{* * *} \\
(0.015)\end{array}$ & $\begin{array}{l}-0.004 \\
(0.018)\end{array}$ & $\begin{array}{c}0.161^{* *} \\
(0.068)\end{array}$ \\
\hline no. instruments & 156 & 156 & 156 \\
\hline $\operatorname{AB} \operatorname{AR}(1)^{\mathrm{a}}$ & 0.000 & 0.000 & 0.005 \\
\hline $\operatorname{AB} \operatorname{AR}(2)^{\mathrm{a}}$ & 0.001 & 0.037 & 0.061 \\
\hline $\operatorname{AB} \operatorname{AR}(3)^{\mathrm{a}}$ & 0.093 & 0.853 & 0.536 \\
\hline Hansen test ${ }^{b}$ & 0.000 & 0.013 & 0.096 \\
\hline Diff Hansen ${ }^{c}$ & 0.059 & 0.386 & 0.000 \\
\hline obs. & 9049 & 6966 & 9143 \\
\hline
\end{tabular}

Regressions included year dummies and a constant. Robust standard errors in parentheses; $* * *,{ }^{*}$ and $*$ denote significance at the $1 \%, 5 \%$ and $10 \%$ level respectively.

${ }^{a}$ Denotes the Arellano-Bond test for no first/second/third order autocorrelation in the first-differenced residuals.

${ }^{b}$ Denotes the Hansen test for the validity of the overidentifying restrictions (p-values reported). $\quad{ }^{\mathrm{c}}$ Denotes the Difference-in-Hansen test for the validity of the additional moment conditions used in the System GMM estimation (p-values reported).

\subsubsection{Income process}

The income process is estimated separately for four different education groups: (1) high education, if the head of household has a degree or higher; (2) medium level education, if the head of household has completed A level education, but does not have a degree ${ }^{13} ;(3)$ low education, if the head of household has completed some form of qualification below A levels, which includes O levels, GCSEs or equivalent, commercial qualifications and apprenticeships; and (4) no formal qualification.

Additional regressors include the age and age squared of the head of household, the number of children and the number of people in employment in the household. The coefficient on lagged income ranges from 0.391 to 0.516 , and is highest for households where the head of household 
Table 4: Income - System GMM estimation by education group

\begin{tabular}{|c|c|c|c|c|}
\hline & $\begin{array}{l}\text { High } \\
(1)\end{array}$ & $\begin{array}{l}\text { Medium } \\
\quad(2)\end{array}$ & $\begin{array}{l}\text { Low } \\
(3)\end{array}$ & $\begin{array}{l}\text { No formal qf. } \\
\text { (4) }\end{array}$ \\
\hline$y_{i, t-1}$ & $\begin{array}{c}0.468^{* * *} \\
(0.049)\end{array}$ & $\begin{array}{c}0.516^{* * *} \\
(0.052)\end{array}$ & $\begin{array}{c}0.391^{* * *} \\
(0.050)\end{array}$ & $\begin{array}{c}0.443^{* * *} \\
(0.050)\end{array}$ \\
\hline age & $\begin{array}{c}0.017^{* * *} \\
(0.005)\end{array}$ & $\begin{array}{c}0.010^{* * *} \\
(0.003)\end{array}$ & $\begin{array}{c}0.013^{* * *} \\
(0.004)\end{array}$ & $\begin{array}{c}0.005 \\
(0.005)\end{array}$ \\
\hline age2 & $\begin{array}{c}-0.000^{* * *} \\
(0.000)\end{array}$ & $\begin{array}{c}-0.000^{* * *} \\
(0.000)\end{array}$ & $\begin{array}{c}-0.000^{* * *} \\
(0.000)\end{array}$ & $\begin{array}{c}-0.000^{* *} \\
(0.000)\end{array}$ \\
\hline no. kids $_{t-1}$ & $\begin{array}{c}0.015 \\
(0.010)\end{array}$ & $\begin{array}{c}0.002 \\
(0.005)\end{array}$ & $\begin{array}{c}0.011 \\
(0.008)\end{array}$ & $\begin{array}{c}0.015 \\
(0.011)\end{array}$ \\
\hline no. employed em-1 $_{t-1}$ & $\begin{array}{c}0.098^{* * *} \\
(0.022)\end{array}$ & $\begin{array}{c}0.085^{* * *} \\
(0.012)\end{array}$ & $\begin{array}{c}0.119^{* * *} \\
(0.018)\end{array}$ & $\begin{array}{c}0.091^{* * *} \\
(0.021)\end{array}$ \\
\hline no. instruments & 139 & 157 & 169 & 169 \\
\hline $\operatorname{AB} \operatorname{AR}(1)^{\mathrm{a}}$ & 0.000 & 0.000 & 0.000 & 0.000 \\
\hline $\operatorname{AB} \operatorname{AR}(2)^{\mathrm{a}}$ & 0.707 & 0.451 & 0.830 & 0.761 \\
\hline $\operatorname{AB} \operatorname{AR}(3)^{\mathrm{a}}$ & 0.508 & 0.288 & 0.655 & 0.371 \\
\hline Hansen test ${ }^{b}$ & 0.044 & 0.489 & 0.324 & 0.571 \\
\hline Diff Hansen ${ }^{c}$ & 0.045 & 0.115 & 0.681 & 0.174 \\
\hline obs. & 4704 & 11426 & 5466 & 3562 \\
\hline
\end{tabular}

Regressions included year dummies and a constant. Robust standard errors in parentheses, and ${ }^{* * *}$ and ${ }^{* *}$ denote significance at the $1 \%$ and $5 \%$ level respectively. a Denotes the Arellano-Bond test for no first/second/third order autocorrelation in the first-differenced residuals. $\quad{ }^{b}$ Denotes the Hansen test for overidentifying restrictions (p-values reported). ${ }^{\mathrm{c}}$ Denotes the Difference-in-Hansen test for the validity of the additional moment conditions used in the System GMM estimation (p-values reported).

has a medium level of education.

\subsection{Bivariate probit model of equity withdrawal and saving}

Estimation results from the pooled bivariate probit model are presented in Table 5 below. The two dependent variables are whether the household has taken out an additional mortgage since the previous year and whether the household actively saves on a regular basis. The advantage of the bivariate approach is that it will capture both the interior and the zero corner solutions, as well as allowing the errors to be correlated across the two variables, providing an estimate of the conditional correlation. If the errors are correlated, then a bivariate approach will produce 
more efficient estimates.

The model is estimated by maximum likelihood, and year, education and employment dummies were included in all estimations ${ }^{14}$. Demographic variables, such as age, education or employment, refer to the household-reference person, and cluster robust standard errors are reported, to control for dependence between observations within households. 
Table 5: Estimation results - bivariate probit model

\begin{tabular}{|c|c|c|c|c|c|}
\hline $\begin{array}{l}\text { Dependent variable: } \\
\text { equity withdrawn }\end{array}$ & $(1)$ & $(2)$ & (3) & $(4)$ & $(5)$ \\
\hline$\Delta \ln \left(\pi_{i t}\right)$ & $\begin{array}{c}0.277^{* * *} \\
(0.066)\end{array}$ & & $\begin{array}{c}0.261^{* * *} \\
(0.063)\end{array}$ & & \\
\hline reg. house price volatility ${ }^{a}$ & $\begin{array}{l}1.386^{* *} \\
(0.692)\end{array}$ & $\begin{array}{l}-0.057 \\
(0.792)\end{array}$ & $\begin{array}{l}1.581^{* *} \\
(0.699)\end{array}$ & $\begin{array}{l}1.380^{* *} \\
(0.693)\end{array}$ & \\
\hline reg. house price inflation & & $\begin{array}{c}1.510^{* * *} \\
(0.373)\end{array}$ & & & \\
\hline$\Delta$ financial expectations ${ }^{\mathrm{b}}$ & & & $\begin{array}{c}0.079 * * * \\
(0.027)\end{array}$ & & \\
\hline$E\left(\Delta y_{i t}\right)$ & & & & $\begin{array}{c}0.587^{* * *} \\
(0.142)\end{array}$ & $\begin{array}{c}0.563^{* * *} \\
(0.144)\end{array}$ \\
\hline$\hat{\epsilon}_{i t}^{y}$ & & & & $\begin{array}{c}-0.437^{* * * *} \\
(0.137)\end{array}$ & $\begin{array}{c}-0.410^{* * * *} \\
(0.139)\end{array}$ \\
\hline$E\left(\Delta \pi_{i t}\right)$ & & & & $\begin{array}{c}0.168 \\
(0.105)\end{array}$ & $\begin{array}{c}0.310^{* *} \\
(0.142)\end{array}$ \\
\hline$\hat{\epsilon}_{i t}^{\pi}$ & & & & $\begin{array}{c}0.317^{* * *} \\
(0.062)\end{array}$ & $\begin{array}{c}0.405^{* * *} \\
(0.097)\end{array}$ \\
\hline$\hat{\sigma_{i t}^{y}}$ & & & & & $\begin{array}{c}-0.155^{* *} \\
(0.076)\end{array}$ \\
\hline$\sigma_{r t}^{\hat{\pi}}$ & & & & & $\begin{array}{l}-0.090^{*} \\
(0.051)\end{array}$ \\
\hline $\ln \left(y_{i t}\right)$ & $\begin{array}{l}0.065^{*} \\
(0.036)\end{array}$ & $\begin{array}{l}0.067^{*} \\
(0.036)\end{array}$ & $\begin{array}{l}0.069^{*} \\
(0.036)\end{array}$ & $\begin{array}{c}0.511^{* * *} \\
(0.125)\end{array}$ & $\begin{array}{c}0.496^{* * *} \\
(0.126)\end{array}$ \\
\hline $\ln ($ assets $)$ & $\begin{array}{c}-0.014^{* * *} \\
(0.004)\end{array}$ & $\begin{array}{c}-0.015^{* * *} \\
(0.004)\end{array}$ & $\begin{array}{c}-0.014^{* * *} \\
(0.004)\end{array}$ & $\begin{array}{c}-0.013^{* * *} \\
(0.004)\end{array}$ & $\begin{array}{c}-0.014^{* * *} \\
(0.004)\end{array}$ \\
\hline $\ln \left(\right.$ mortgage $\left._{i, t-1}\right)$ & $\begin{array}{c}0.112^{* * *} \\
(0.009)\end{array}$ & $\begin{array}{c}0.110^{* * *} \\
(0.009)\end{array}$ & $\begin{array}{c}0.115^{* * *} \\
(0.009)\end{array}$ & $\begin{array}{c}0.113^{* * *} \\
(0.009)\end{array}$ & $\begin{array}{c}0.112^{* * *} \\
(0.009)\end{array}$ \\
\hline endowment mortgage & $\begin{array}{c}0.055 \\
(0.040)\end{array}$ & $\begin{array}{c}0.063 \\
(0.041)\end{array}$ & $\begin{array}{c}0.048 \\
(0.040)\end{array}$ & $\begin{array}{c}0.054 \\
(0.040)\end{array}$ & $\begin{array}{c}0.055 \\
(0.040)\end{array}$ \\
\hline moved & $\begin{array}{c}-0.379^{* * *} \\
(0.072)\end{array}$ & $\begin{array}{c}-0.328^{* * *} \\
(0.070)\end{array}$ & $\begin{array}{c}-0.401^{* * *} \\
(0.073)\end{array}$ & $\begin{array}{c}-0.394^{* * *} \\
(0.071)\end{array}$ & $\begin{array}{c}-0.394^{* * *} \\
(0.073)\end{array}$ \\
\hline age & $\begin{array}{c}0.014 \\
(0.014)\end{array}$ & $\begin{array}{c}0.013 \\
(0.014)\end{array}$ & $\begin{array}{c}0.013 \\
(0.014)\end{array}$ & $\begin{array}{l}-0.001 \\
(0.014)\end{array}$ & $\begin{array}{c}0.000 \\
(0.014)\end{array}$ \\
\hline age squared & $\begin{array}{l}-0.000 \\
(0.000)\end{array}$ & $\begin{array}{l}-0.000 \\
(0.000)\end{array}$ & $\begin{array}{l}-0.000 \\
(0.000)\end{array}$ & $\begin{array}{l}-0.000 \\
(0.000)\end{array}$ & $\begin{array}{l}-0.000 \\
(0.000)\end{array}$ \\
\hline no. kids & $\begin{array}{c}0.076^{* * *} \\
(0.016)\end{array}$ & $\begin{array}{c}0.077^{* * *} \\
(0.016)\end{array}$ & $\begin{array}{c}0.080^{* * *} \\
(0.016)\end{array}$ & $\begin{array}{c}0.076^{* * *} \\
(0.016)\end{array}$ & $\begin{array}{c}0.074^{* * *} \\
(0.016)\end{array}$ \\
\hline got married & $\begin{array}{c}0.084 \\
(0.090)\end{array}$ & $\begin{array}{c}0.082 \\
(0.091)\end{array}$ & $\begin{array}{l}0.087 \\
(0.092)\end{array}$ & $\begin{array}{c}0.078 \\
(0.091)\end{array}$ & $\begin{array}{c}0.077 \\
(0.091)\end{array}$ \\
\hline got divorced & $\begin{array}{c}0.530^{* * *} \\
(0.115)\end{array}$ & $\begin{array}{c}0.524^{* * *} \\
(0.115)\end{array}$ & $\begin{array}{c}0.534^{* * *} \\
(0.116)\end{array}$ & $\begin{array}{c}0.564^{* * *} \\
(0.116)\end{array}$ & $\begin{array}{c}0.580^{* * *} \\
(0.116)\end{array}$ \\
\hline$\Delta$ employed & $\begin{array}{l}-0.042 \\
(0.027)\end{array}$ & $\begin{array}{l}-0.042 \\
(0.027)\end{array}$ & $\begin{array}{l}-0.024 \\
(0.026)\end{array}$ & $\begin{array}{l}-0.002 \\
(0.030)\end{array}$ & $\begin{array}{l}-0.006 \\
(0.030)\end{array}$ \\
\hline
\end{tabular}


Table 5: Estimation results - bivariate probit model (continued)

\begin{tabular}{|c|c|c|c|c|c|}
\hline $\begin{array}{l}\text { Dependent variable: } \\
\text { saves from current income }\end{array}$ & (1) & $(2)$ & (3) & $(4)$ & (5) \\
\hline$\Delta \ln \left(\pi_{i t}\right)$ & $\begin{array}{c}0.027 \\
(0.026)\end{array}$ & & $\begin{array}{c}0.026 \\
(0.026)\end{array}$ & & \\
\hline reg. house price volatility ${ }^{a}$ & $\begin{array}{c}0.432 \\
(0.505)\end{array}$ & $\begin{array}{c}0.465 \\
(0.583)\end{array}$ & $\begin{array}{c}0.413 \\
(0.508)\end{array}$ & $\begin{array}{c}0.456 \\
(0.511)\end{array}$ & \\
\hline reg. house price inflation & & $\begin{array}{l}-0.022 \\
(0.250)\end{array}$ & & & \\
\hline$\Delta$ financial expectations ${ }^{\mathrm{b}}$ & & & $\begin{array}{l}-0.026 \\
(0.019)\end{array}$ & & \\
\hline$E\left(\Delta y_{i t}\right)$ & & & & $\begin{array}{c}0.100 \\
(0.109)\end{array}$ & $\begin{array}{c}0.042 \\
(0.109)\end{array}$ \\
\hline$\hat{\epsilon}_{i t}^{y}$ & & & & $\begin{array}{c}-0.323^{* * *} \\
(0.108)\end{array}$ & $\begin{array}{c}-0.273^{* *} \\
(0.108)\end{array}$ \\
\hline$E\left(\Delta \pi_{i t}\right)$ & & & & $\begin{array}{l}-0.004 \\
(0.079)\end{array}$ & $\begin{array}{c}0.042 \\
(0.083)\end{array}$ \\
\hline$\hat{\epsilon}_{i t}^{\pi}$ & & & & $\begin{array}{c}0.032 \\
(0.029)\end{array}$ & $\begin{array}{c}0.035 \\
(0.035)\end{array}$ \\
\hline$\sigma_{i t}^{y}$ & & & & & $\begin{array}{c}-0.338^{* * *} \\
(0.050)\end{array}$ \\
\hline$\hat{\sigma_{r t}^{\hat{\pi}}}$ & & & & & $\begin{array}{c}-0.127 * * * \\
(0.030)\end{array}$ \\
\hline $\ln \left(y_{i t}\right)$ & $\begin{array}{c}0.439^{* * *} \\
(0.031)\end{array}$ & $\begin{array}{c}0.439 * * * \\
(0.031)\end{array}$ & $\begin{array}{c}0.436^{* * *} \\
(0.031)\end{array}$ & $\begin{array}{c}0.656^{* * *} \\
(0.100)\end{array}$ & $\begin{array}{c}0.629 * * * \\
(0.100)\end{array}$ \\
\hline $\ln ($ assets $)$ & $\begin{array}{c}0.072^{* * *} \\
(0.003)\end{array}$ & $\begin{array}{c}0.073^{* * *} \\
(0.004)\end{array}$ & $\begin{array}{c}0.072^{* * *} \\
(0.004)\end{array}$ & $\begin{array}{c}0.072^{* * *} \\
(0.003)\end{array}$ & $\begin{array}{c}0.072^{* * *} \\
(0.003)\end{array}$ \\
\hline $\ln \left(\right.$ mortgage $\left._{i, t-1}\right)$ & $\begin{array}{c}0.000 \\
(0.004)\end{array}$ & $\begin{array}{l}-0.000 \\
(0.004)\end{array}$ & $\begin{array}{l}0.000 \\
(0.004)\end{array}$ & $\begin{array}{l}-0.001 \\
(0.004)\end{array}$ & $\begin{array}{l}-0.002 \\
(0.004)\end{array}$ \\
\hline$M_{i t}$ & $\begin{array}{c}-0.977^{* * *} \\
(0.223)\end{array}$ & $\begin{array}{c}-0.868^{* * *} \\
(0.271)\end{array}$ & $\begin{array}{c}-1.009 * * * \\
(0.206)\end{array}$ & $\begin{array}{c}-0.955^{* * *} \\
(0.229)\end{array}$ & $\begin{array}{c}-0.926 * * * \\
(0.241)\end{array}$ \\
\hline moved $_{i t}$ & $\begin{array}{c}-0.187^{* * *} \\
(0.039)\end{array}$ & $\begin{array}{c}-0.180^{* * *} \\
(0.039)\end{array}$ & $\begin{array}{c}-0.182^{* * *} \\
(0.039)\end{array}$ & $\begin{array}{c}-0.184^{* * *} \\
(0.039)\end{array}$ & $\begin{array}{c}-0.146 * * * \\
(0.040)\end{array}$ \\
\hline age & $\begin{array}{l}-0.009 \\
(0.006)\end{array}$ & $\begin{array}{l}-0.009 \\
(0.006)\end{array}$ & $\begin{array}{l}-0.009 \\
(0.006)\end{array}$ & $\begin{array}{c}-0.017^{* *} \\
(0.007)\end{array}$ & $\begin{array}{c}-0.015^{* *} \\
(0.007)\end{array}$ \\
\hline age squared & $\begin{array}{c}0.000 \\
(0.000)\end{array}$ & $\begin{array}{l}0.000 \\
(0.000)\end{array}$ & $\begin{array}{l}0.000 \\
(0.000)\end{array}$ & $\begin{array}{l}0.000 \\
(0.000)\end{array}$ & $\begin{array}{c}0.000 \\
(0.000)\end{array}$ \\
\hline no. kids & $\begin{array}{c}-0.087 * * * \\
(0.017)\end{array}$ & $\begin{array}{c}-0.089^{* * * *} \\
(0.017)\end{array}$ & $\begin{array}{c}-0.086 * * * \\
(0.017)\end{array}$ & $\begin{array}{c}-0.088^{* * * *} \\
(0.017)\end{array}$ & $\begin{array}{c}-0.091^{* * *} \\
(0.017)\end{array}$ \\
\hline got married & $\begin{array}{l}0.042 \\
(0.063)\end{array}$ & $\begin{array}{c}0.042 \\
(0.063)\end{array}$ & $\begin{array}{c}0.039 \\
(0.064)\end{array}$ & $\begin{array}{c}0.044 \\
(0.063)\end{array}$ & $\begin{array}{c}0.047 \\
(0.063)\end{array}$ \\
\hline got divorced & $\begin{array}{c}-0.308^{* * *} \\
(0.090)\end{array}$ & $\begin{array}{c}-0.321^{* * *} \\
(0.092)\end{array}$ & $\begin{array}{c}-0.315^{* * *} \\
(0.090)\end{array}$ & $\begin{array}{c}-0.301^{* * *} \\
(0.090)\end{array}$ & $\begin{array}{c}-0.281^{* * *} \\
(0.092)\end{array}$ \\
\hline$\Delta$ employed & $\begin{array}{c}0.022 \\
(0.015)\end{array}$ & $\begin{array}{c}0.023 \\
(0.015)\end{array}$ & $\begin{array}{l}0.017 \\
(0.015)\end{array}$ & $\begin{array}{c}0.055^{* * *} \\
(0.018)\end{array}$ & $\begin{array}{c}0.046^{* *} \\
(0.018)\end{array}$ \\
\hline$\rho^{\mathrm{c}}$ & $\begin{array}{c}0.466^{* * *} \\
(0.135)\end{array}$ & $\begin{array}{l}0.401^{* *} \\
(0.156)\end{array}$ & $\begin{array}{c}0.489^{* * *} \\
(0.127)\end{array}$ & $\begin{array}{c}0.453^{* * *} \\
(0.137)\end{array}$ & $\begin{array}{c}0.433^{* * *} \\
(0.142)\end{array}$ \\
\hline $\begin{array}{l}\text { log-pseudo likelihood } \\
\text { households/observations }\end{array}$ & $\begin{array}{c}-19797.632 \\
5612 / 25158\end{array}$ & $\begin{array}{c}-19801.644 \\
5612 / 25158\end{array}$ & $\begin{array}{c}-19215.87 \\
5561 / 24452\end{array}$ & $\begin{array}{c}-19775.095 \\
5612 / 25158\end{array}$ & $\begin{array}{c}-19718.546 \\
5612 / 25158\end{array}$ \\
\hline $\begin{array}{l}\text { Coefficient estimates are } \mathrm{r} \\
* * \text { and } * \text { denote significanc } \\
\text { mies were included in all es } \\
\text { deviation of the change in } \\
\text { price data, as in Banks et } \\
\text { captures the change in hou }\end{array}$ & $\begin{array}{l}\text { d, not margi } \\
\text { e } 1 \%, 5 \% \text { an } \\
\text { ons. a Thi } \\
\text { real house p } \\
10) \text { b Th } \\
\text { expectation }\end{array}$ & $\begin{array}{l}\text { effects. Cl } \\
\% \text { level res } \\
\text { easure of h } \\
\text { over previ } \\
\text { efers to the }\end{array}$ & $\begin{array}{l}\text { robust star } \\
\text { vely. Year, } \\
\text { price volati } \\
\text { ve years fo } \\
\text { ective finan }\end{array}$ & $\begin{array}{l}\text { errors in } p \\
\text { ation and e } \\
\text { s calculated } \\
\text { region usi } \\
\text { expectation } \\
\text { (1=improve }\end{array}$ & $\begin{array}{l}\text { entheses. }{ }^{* * *} \text {, } \\
\text { loyment dum- } \\
\text { the standard } \\
\text { Halifax house } \\
\text { ariable, which } \\
0=\text { no change, }\end{array}$ \\
\hline
\end{tabular}


Column (1) presents the results for the baseline model, which focuses on the impact of realised housing capital gains, $\Delta \ln \left(\pi_{i t}\right)$, and regional house price volatility on the propensity to withdraw equity and save. In Column (2), realised housing capital gains are replaced with a measure of regional house price inflation, and in Column (3) a control for households' subjective financial expectations is included in the model. Columns (4) and (5) include the full set of sample-based expectational variables, as well as a sample-based measure of house price and income volatility. Demographic and socio-economic variables were included in all specifications.

The results confirm that the decision to remortgage and the decision to save are not independent, as evidenced by the positive and statistically significant estimate of the conditional correlation parameter $\rho$. This is consistent with the findings of Brown et al. (2008) and suggests there are significant efficiency gains from estimating these two decisions jointly ${ }^{15}$. The results also point to some interesting differences in what drives individual borrowing and saving behaviour. If borrowing were viewed simply as negative saving, then we would expect variables that have a positive impact on borrowing to have a negative impact on saving, and vice-versa. The results suggest this is in fact the case for some variables: for example, the number of children in the household and getting divorced increase the likelihood the household will remortgage and decrease the likelihood they will save. However, for other variables the estimated effects have the same sign for both the remortgage and saving decisions. These cases will be discussed in more detail below.

The results in Column (1) suggest households withdraw equity to take advantage of housing capital gains, which may reflect both wealth or collateral effects. This is consistent with the findings in Benito (2009), although his results are based on a measure of regional house price inflation. Disney et al. (2010a), in their analysis of the impact of changes in house prices on mortgage equity withdrawal for the UK, find that these are only significant for households with high levels of unsecured debt, suggesting it is mainly collateral effects that are at work here. 
Regional house price volatility has a positive and significant impact on the equity withdrawal decision, which is at odds both with the theory and with the findings in Banks et al. (2010) and Benito (2009). When the household-level measure of capital gains is replaced with a measure of regional house price inflation based on house price data from the Halifax bank ${ }^{16}$ (column 2), both variables have the expected sign, although the volatility measure is no longer significant.

Realised housing capital gains do not have a significant impact on household saving behaviour, and while the impact of both regional house price inflation and volatility on the propensity to save have the expected sign, neither variable is significant.

The specification in column (3) includes a measure of households' financial expectations, based on the subjective financial expectations variable available in the BHPS $^{17}$. This has a positive and statistically significant effect on the propensity to remortgage, which is consistent with the findings in Brown et al. (2005) that optimistic financial expectations have a positive impact on the level and growth of debt. In line with the findings in Disney et al. (2010b), optimistic financial expectations have a negative impact on the propensity to save, although this is not statistically significant.

Turning to the results in columns (4) and (5), these suggest that both anticipated changes in house prices and house price shocks affect household consumption primarily through the decision to remortgage and not the decision to save. Shocks to the value of housing wealth have a positive and significant impact on the propensity to withdraw equity, which supports the view that households withdraw equity to take advantage of unanticipated house price gains, although it may also reflect an unbinding of borrowing constraints, allowing previously constrained households to increase their mortgage borrowing. Anticipated increases in housing wealth also have a positive and significant impact on the propensity to withdraw equity, after controlling for income and house price volatility, which further suggests that increases in house prices relax the borrowing constraints households face. The impact of house price shocks on the propensity to save is 
positive, but it is not statistically significant, in contrast to the results in Disney et al. (2010b) who find a small but significant negative impact of house price shocks on household saving for UK homeowners. However their measure of saving explicitly includes retirement saving and they use county-level house price data to derive their measure of house price shocks.

Interestingly, the sample-based measures of house price and income volatility ${ }^{18}$ have a negative and significant impact on both the decision to remortgage and the decision to save. Greater uncertainty in income or housing wealth increases the risks of withdrawing housing equity, therefore the negative impact of these variables on the propensity to remortgage is consistent with the theory and with the findings of Benito (2009) and Banks et al. (2010). In theory we would expect households to increase savings when faced with greater uncertainty in income or wealth, particularly if precautionary saving motives are important (Pistaferri, 2001). The negative impact found here may reflect the fact that greater house price volatility limits an individual's ability to borrow and therefore households will need to rely on decreasing saving to smooth their consumption instead, while greater income volatility may make it more difficult for households to save.

Income shocks also have a negative impact on both the decision to remortgage and the decision to save. An unexpected increase in income allows households to boost their consumption without having to resort to borrowing, however income shocks should have a positive impact on the propensity to save ${ }^{19}$ (Pistaferri, 2001). One possible explanation for these findings is that precautionary saving motives may be weaker in the presence of housing wealth. Alternatively, they may reflect a high degree of impatience or myopic behaviour by households.

Anticipated changes in income only have a significant impact on the propensity to withdraw equity, which is consistent with a consumption-smoothing role for equity withdrawal, where households use their housing equity to borrow against expected rising future incomes. These same anticipated changes in income should have a negative impact on the propensity to save. 
The fact that the estimated impact on saving is not significant may reflect the fact that saving was already low and households are unable to run down assets further.

The impact of the additional control variables is largely consistent with the theory and the findings in earlier studies. Current income has a positive effect on both the propensity to remortgage and the propensity to save. A higher level of income makes it easier to save on a regular basis, but income also places a constraint on access to borrowing. The fact that current income has a positive effect on the propensity to remortgage may therefore reflect either households' unwillingness to increase their debt burden when their incomes are lower, or difficulties faced by households with lower incomes in accessing credit.

The stock of financial assets has a negative and significant effect on the propensity to remortgage, which suggests that households are more likely to remortgage if they are liquidity constrained (Benito, 2009; Hurst and Stafford, 2004). The fact that this variable has a positive and significant impact on the propensity to save may be capturing households' preferences, suggesting that some households have a stronger preference for saving.

Turning to the mortgage-related variables, whether the household recently withdrew equity has a negative and highly significant impact on the propensity to save. If precautionary saving or portfolio rebalancing motives are important, then we would expect equity withdrawal to have a positive impact on saving. However equity withdrawal raises monthly mortgage costs - average real monthly mortgage payments are $£ 517$ for households who recently withdrew equity, against $£ 388$ for households with a mortgage but who did not withdraw equity - and therefore decreases the income households have available to save.

The lagged level of mortgage debt has a positive effect on the propensity to remortgage, which offers some support for financial efficiency motives for remortgaging. As a robustness check, the model was also estimated using the mortgage interest rate and the interest rate differential ${ }^{20}$. Both had a positive and significant impact, which is counterintuitive, although Hurst and Stafford 
(2004) do find that US households remortgage even in periods of high and rising interest rates when faced with negative financial shocks, particularly if they have low levels of liquid assets to draw on.

Having an endowment mortgage does not have a significant impact on the propensity to remortgage, which is consistent with the findings in Benito (2009). Endowment mortgages expose households to additional sources of risk, since the repayment of the mortgage principal depends on the performance of the associated investment fund, and therefore may induce households to save. As a robustness check, the model was estimated including this variable in the savings equation and was found to have a small positive and significant impact.

Households that have moved house recently are significantly less likely to remortgage. Moving house is a significant source of equity release and households that move are more likely to withdraw equity by overmortgaging, that is, increasing the mortgage on their new property by more than the increase in value of their new property relative to their old one (Benito, 2009). Perhaps unsurprisingly, moving home - a potentially very expensive activity - also has a negative impact on the propensity to save. In the sample there were only 97 households who moved and increased their mortgage borrowing at the same time; as an additional robustness check, the model was estimated on the sub-sample of households that did not move house during the sample period and the results are reported in Table 9 in the Appendix. The main results are unchanged, although the sample-based house price volatility measure no longer has a significant impact on the equity withdrawal decision. Regional house price inflation now has a positive effect on saving but it is not statistically significant.

Thee results for the remaining demographics and socio-economic characteristics are largely consistent with the predictions of lifecycle theory. Age does not appear to have a significant impact on the propensity to remortgage, but does have a negative effect on the propensity to save. Whether saving is expected to increase or decrease with age will depend on what stage of 
the lifecycle the household is at, which provides a rationale for estimating the model separately for different age groups (these results are reported in section 5.3). The number of children in the household also has a positive and significant effect on the propensity to remortgage, and a negative effect on the propensity to save. Getting divorced, as a measure of non-financial shocks, has a statistically significant impact, which is positive in the case of the remortgaging decision, consistent with the findings in Benito (2009) and Bridges et al. (2006), and negative in the case of the household saving decision.

\subsubsection{Marginal effects}

The results above suggest that both realised house price gains and expected and unexpected changes in house prices have an impact on the equity withdrawal decision, although they do not have a direct impact on household saving. In this section, the marginal effects associated with these variables were derived, in order to gauge the relative magnitude of the impact associated with each variable.

Calculating marginal effects following estimation of a bivariate probit model is complicated by the fact that there are different conditional quantities that might be analysed (Greene, 1996). Given that the focus of this paper is on remortgaging and saving, Table 6 below reports the marginal effects associated with the joint distribution of household remortgaging and saving. The marginal effects associated with realised capital gains are computed following estimation of the model presented in column (1) in Table 5 and the marginal effects associated with house price shocks are calculated following estimation of the model presented in column (5) in Table 5.

The impact of house price shocks on the probability that the household will remortgage is proportionately larger than the impact of realised house price gains and anticipated changes in housing wealth (columns (1) and (2)), which suggests that innovations to house prices do play a significant role in driving household borrowing and saving behaviour beyond the role of realised 
capital gains. What is more interesting perhaps is the fact that the impact of these variables on the probability that the household remortgages and saves is positive and significantly larger than their impact on the probability that the households remortgages and does not save. This suggests that while households do increase their borrowing in response to rising house values, some of these households are also insuring themselves against possible falls in house prices.

Table 6: Marginal effects for joint probabilities

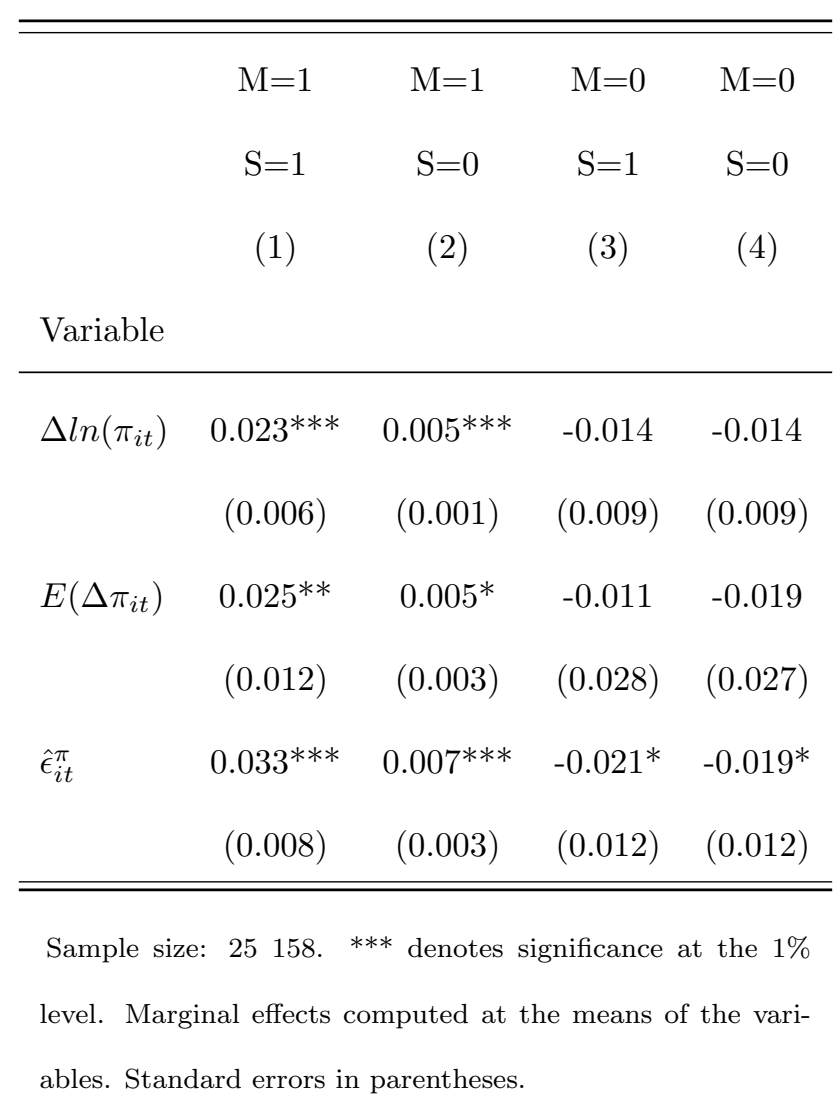

\subsection{Equity withdrawal and saving over the lifecycle}

Housing demands and individual motives and constraints on remortgaging and saving vary over the lifecycle, and therefore there is no reason to assume that households at different stages of the lifecycle should respond in the same way to changes in house prices. In order to analyse whether 
there are any systematic differences in the remortgaging and saving behaviour of households at different stages of the lifecycle in response to realised house price gains and house price shocks, models (1) and (5) in Table 5 were estimated separately for two different age groups: younger households, where the head of household is aged between 30 and 50; and older households, where the head of household is aged over 50 . This also provides a means for controlling for the possibility that the savings variable used is capturing retirement saving.

The summary results are reported in Table 7 and the full results are available in Table 10 in the Appendix. 
Table 7: Estimation results by age group - bivariate probit model

\begin{tabular}{|c|c|c|c|c|}
\hline \multirow{2}{*}{$\begin{array}{l}\text { Dependent variable: } \\
\text { equity withdrawn }\end{array}$} & \multicolumn{2}{|c|}{ 30-50 Age group } & \multicolumn{2}{|c|}{$50+$ Age group } \\
\hline & $(1)$ & $(2)$ & (3) & $(4)$ \\
\hline$\Delta \ln \left(\pi_{i t}\right)$ & $\begin{array}{c}0.263^{* * *} \\
(0.075)\end{array}$ & & $\begin{array}{c}0.070 \\
(0.182)\end{array}$ & \\
\hline reg. house price volatility ${ }^{a}$ & $\begin{array}{c}1.683^{* *} \\
(0.815)\end{array}$ & & $\begin{array}{l}1.134 \\
(1.687)\end{array}$ & \\
\hline$E\left(\Delta y_{i t}\right)$ & & $\begin{array}{c}0.590^{* * *} \\
(0.174)\end{array}$ & & $\begin{array}{c}0.498 \\
(0.315)\end{array}$ \\
\hline$\hat{\epsilon}_{i t}^{y}$ & & $\begin{array}{c}-0.385^{* *} \\
(0.168)\end{array}$ & & $\begin{array}{c}0.005 \\
(0.305)\end{array}$ \\
\hline$E\left(\Delta \pi_{i t}\right)$ & & $\begin{array}{c}0.386^{* *} \\
(0.182)\end{array}$ & & $\begin{array}{l}-0.099 \\
(0.234)\end{array}$ \\
\hline$\hat{\epsilon}_{i t}^{\pi}$ & & $\begin{array}{c}0.477^{* * *} \\
(0.139)\end{array}$ & & $\begin{array}{c}0.096 \\
(0.126)\end{array}$ \\
\hline$\hat{\sigma}_{i t}^{y}$ & & $\begin{array}{l}-0.146 \\
(0.092)\end{array}$ & & $\begin{array}{c}-0.443^{* *} \\
(0.206)\end{array}$ \\
\hline$\hat{\sigma_{r t}}$ & & $\begin{array}{l}-0.126^{*} \\
(0.075)\end{array}$ & & $\begin{array}{r}0.072^{* *} \\
(0.036)\end{array}$ \\
\hline
\end{tabular}

\begin{tabular}{|c|c|c|c|c|}
\hline \multirow{2}{*}{$\begin{array}{l}\text { Dependent variable: } \\
\text { saves from current income }\end{array}$} & \multicolumn{2}{|c|}{ 30-50 Age group } & \multicolumn{2}{|c|}{$50+$ Age group } \\
\hline & (1) & $(2)$ & (3) & (4) \\
\hline$\Delta \ln \left(\pi_{i t}\right)$ & $\begin{array}{l}-0.004 \\
(0.034)\end{array}$ & & $\begin{array}{c}0.011 \\
(0.043)\end{array}$ & \\
\hline reg. house price volatility ${ }^{\mathrm{a}}$ & $\begin{array}{c}0.875 \\
(0.752)\end{array}$ & & $\begin{array}{l}-0.003 \\
(0.754)\end{array}$ & \\
\hline$E\left(\Delta y_{i t}\right)$ & & $\begin{array}{l}0.267^{*} \\
(0.159)\end{array}$ & & $\begin{array}{l}-0.046 \\
(0.162)\end{array}$ \\
\hline$\hat{\epsilon}_{i t}^{y}$ & & $\begin{array}{c}-0.344^{* *} \\
(0.154)\end{array}$ & & $\begin{array}{l}-0.260 \\
(0.163)\end{array}$ \\
\hline$E\left(\Delta \pi_{i t}\right)$ & & $\begin{array}{l}-0.017 \\
(0.113)\end{array}$ & & $\begin{array}{c}0.082 \\
(0.123)\end{array}$ \\
\hline$\hat{\epsilon}_{i t}^{\pi}$ & & $\begin{array}{l}0.017 \\
(0.052)\end{array}$ & & $\begin{array}{l}-0.017 \\
(0.054)\end{array}$ \\
\hline$\hat{\sigma}_{i t}^{\hat{y}}$ & & $\begin{array}{c}-0.389^{* * *} \\
(0.077)\end{array}$ & & $\begin{array}{c}-0.266^{* * *} \\
(0.074)\end{array}$ \\
\hline$\sigma_{r t}^{\hat{\pi}}$ & & $\begin{array}{c}-0.072^{* *} \\
(0.029)\end{array}$ & & $\begin{array}{c}-0.224^{* * * *} \\
(0.059)\end{array}$ \\
\hline$\rho^{\mathrm{c}}$ & $\begin{array}{c}0.356^{* *} \\
(0.179)\end{array}$ & $\begin{array}{l}0.331^{*} \\
(0.186)\end{array}$ & $\begin{array}{l}0.600^{* *} \\
(0.304)\end{array}$ & $\begin{array}{l}0.675^{* *} \\
(0.317)\end{array}$ \\
\hline $\begin{array}{l}\text { log-pseudo likelihood } \\
\text { observations }\end{array}$ & $\begin{array}{c}-10071.588 \\
3090 / 11724\end{array}$ & $\begin{array}{c}-10029.53 \\
3090 / 11724\end{array}$ & $\begin{array}{c}-7562.884 \\
2528 / 10981\end{array}$ & $\begin{array}{c}-7521.105 \\
2528 / 10981\end{array}$ \\
\hline
\end{tabular}


From the results in Table 7 it is clear that changes in house prices only have an impact on the equity withdrawal decisions of younger households: realised house price gains and expected and unexpected changes in house prices increase the likelihood that younger households will access their housing equity, after controlling for house price volatility. Income shocks have the expected negative impact on the propensity to withdraw equity, whereas expected changes in income have a positive and significant impact, which is consistent with a consumption-smoothing role for equity withdrawal, where younger households use their housing equity to borrow against expected rising future incomes.

The results do not seem to suggest that the savings variable used is capturing retirement saving. In line with the findings for the full sample, realised house price gains and both anticipated and unanticipated changes in housing wealth do not have a significant impact on saving, either for young or older households. Saving decisions seem to be much more responsive to changes in income, particularly for younger households: income shocks have a negative impact on the likelihood these households will save, while anticipated changes in income have the opposite effect. Under the assumptions of the traditional lifecycle/permanent income hypothesis, households should respond to expected increases in income by bringing consumption forward, either by borrowing or running down assets, so this positive and significant impact of anticipated income changes is somewhat puzzling.

Greater house price volatility has the expected negative impact on the equity withdrawal decision for younger households, however it has a positive impact for older households. This may reflect the fact that older households are less likely to want to move in the future and are therefore less susceptible to short-term fluctuations in house prices. This is consistent with the argument and findings in Banks et al. (2010), that young households living in areas with greater house price volatility are less likely to withdraw housing equity.

Income volatility decreases the likelihood that households will withdraw equity, but this is 
only significant for older households, which may reflect the fact that these households are closer to retirement and therefore greater income uncertainty increases the risk they will be unable to repay any additional borrowing.

In line with the results for the full sample, both income and house price volatility have a negative and significant impact on the decision to save, suggesting that greater income volatility may make it more difficult for households to save, while greater house price volatility may limit an individual's ability or willingness to borrow, forcing households to rely on decreasing saving to smooth their consumption instead.

\section{Conclusion}

There has recently been a renewed interest in understanding whether, and how, house prices affect consumption, and most of the applied microeconomic work in this area has focused on estimating models of household consumption which incorporate housing wealth. This paper proposes an alternative approach to this question by focusing on the impact of changes in housing wealth on household borrowing and saving simultaneously. For homeowners, if house prices do have an impact on consumption, then households should respond to increases in their housing wealth by either decreasing their saving or by borrowing more.

Data from the British Household Panel Survey for the period between 1995 and 2007 is used to explore the impact of changes in housing wealth on the household decision to withdraw housing equity and save in the context of a recursive bivariate probit model, controlling for income expectations. Unlike previous work on the mortgage equity withdrawal decision, this paper distinguishes between the impact of realised capital gains and house price expectations, which are derived from a first-stage regression of a model for house prices.

The results suggest that the decision to withdraw housing equity and the decision to save are 
not independent: the estimated conditional correlation parameter in the bivariate probit model is positive and statistically significant. Realised house price gains and anticipated and unanticipated changes in house prices affect household consumption primarily through the decision to remortgage and not the decision to save, but this is mainly for younger households. Saving decisions seem to be much more responsive to changes in income, particularly for younger households. However while changes in housing wealth have no direct impact on household saving, either for young or older homeowners, they do have an important indirect impact, since they increase the likelihood the household will withdraw equity, which in turn has a negative impact on household saving. The magnitude of the effect of unexpected changes in house prices is larger than the impact of realised house price gains, but the impact of both these variables on the probability that the household remortgages and saves is positive and significantly larger than their impact on the probability the households remortgages and does not save. This suggests that while households do increase their borrowing in response to rising house values, they are also insuring themselves against possible falls in house prices.

These findings have important implications given the fluctuations in house prices in the UK observed in recent years and the fact that housing is the largest asset in most household portfolios. They also go some way towards explaining the sharp increase in housing equity withdrawal and decline in household saving observed in the UK from the end of the 1990s until the onset of the recent financial crisis.

\section{Notes}

\footnotetext{
${ }^{1}$ Households are long in housing if the fundamental value of the house they own is greater than the presented discounted value of their future consumption of housing services.

${ }^{2}$ These are defined as households that owned their home outright or with a mortgage.

${ }^{3}$ The actual question households are asked is: "Have you taken out any additional mortgage or loan on this
} 
house/flat since September [previous year]?"

${ }^{4}$ The exact wording of the question is "Do you save any amount of your income, for example by putting something away now and then in a bank, building society, or Post Office account other than to meet regular bills?" Disney et al. (2010b) use this variable together with household contributions to private pension schemes as a measure of active saving, however in this paper the focus in only on the former in order to abstract from retirement saving.

${ }^{5}$ The chi-square statistic is 1.9724 , with a p-value of 0.160

${ }^{6}$ Detailed asset data is only collected in three of the years of the sample (1995, 2000 and 2005). The measure of household assets makes use of the information for all three years, but assumes that holdings of financial assets do not change in the intervening period. Missing wealth data was imputed following the approach in Banks et al. $(2002)$

${ }^{7}$ Income volatility is computed for each household $i$ in the sample. To allow for the fact that some households may move across regions, the measure of house price volatility is based on the variance of house values within each region, $r$.

${ }^{8}$ For example, Ebner (2010), Benito (2009), Bridges et al. (2006).

${ }^{9}$ Disney et al. (2010a) allow for possible selectivity between movers and non-movers in the sample by controlling for the probability that the household does not move; however here I follow Benito (2009) and simply include a dummy for whether the household has moved in the estimation.

${ }^{10}$ This dataset does include a measure of households' subjective financial expectations, but this is a single categorical variable and therefore it would not be possible to separately identify the impact of these two variables, or to distinguish between expected and unexpected shocks.

${ }^{11}$ See for example Browning et al. (2013), Dominitz (2001) and Banks et al. (2001).

${ }^{12}$ The results are not reported here, but are available on request.

${ }^{13}$ This category also includes households where the head of household completed a higher qualification, such as a teaching or nursing qualification.

${ }^{14}$ The results for education and employment status were not reported in the tables due to space considerations, however they are available on request. For the remortgaging decision, only the highest education level had a significant impact, and only under two of the specifications; among the employment status variables, only being unemployed or retired were statistically significant and had the expected negative sign. The direction of the effect of education and employment variables on the propensity to save was largely consistent with the theory, with a higher level of education having a positive effect on the propensity to save, while being self-employed, unemployed 
or retired had a negative impact.

${ }^{15}$ The errors may also be correlated if a variable that affects both the household decision to remortgage and save has been omitted from the regressions. The choice of variables used here is motivated by a review of existing work and tests were carried out to rule out other explanatory variables from the model.

${ }^{16}$ This is computed as the change in the log average house price for each region using Halifax house price data, which is then mapped on to the BHPS sample.

${ }^{17}$ This variable is based on respondent's answer to the question: "Looking ahead, how do you think you yourself will be financially a year from now, will you be better than now/worse than now/ about the same?" The variable is measured on a three-point scale, where $1=$ improved, $0=$ no change, and $-1=$ worsened, as in Disney et al. (2010a).

${ }^{18}$ Income and house price volatility are proxied using the squared residuals from the regressions for income and house prices.

${ }^{19}$ According to the permanent income hypothesis, savings should only respond to transitory shocks to income and not permanent shocks. Savings may respond to both transitory and permanent shocks if buffer-stock saving motives are important (as in Deaton (1991) or Carroll (2009)). Since the focus of this paper is on the impact of changes in housing wealth, we do not distinguish between permanent and transitory shocks to income.

${ }^{20}$ The interest rate differential here was calculated as the difference between the standard variable mortgage rate to households of UK financial institutions and the interest rate on instant access deposits collected from the Bank of England.

\section{References}

University of Essex. Institute for Social and Economic Research, British Household Panel Survey: Waves 1-18, 1991-2009 [computer file]. 7th edition. Colchester, Essex: UK Data Archive [distributor], July 2010. SN: 5151.

Angelini, V. and Simmons, P. (2005). Housing debt, employment risk and consumption. Discussion Papers in Economics. University of York Discussion Paper no. 2005/07.

Arellano, M. and Bover, O. (1995). Another look at the instrumental variable estimation of error-components models. Journal of Econometrics, 68:29-51. 
Attanasio, O., Blow, L., Hamilton, R., and Leicester, A. (2009). Booms and busts: consumption, house prices and expectations. Economica, 76:20-50.

Attanasio, O. and Weber, G. (1994). The uk consumption boom of the late 1980s: aggregate implications of microeconomic evidence. The Economic Journal, 104:1269-1302.

Banks, J., Blundell, R., Oldfield, Z., and Smith, J. (2010). House price volatility and the housing ladder. IZA Discussion Papers 5173, Institute for the Study of Labor (IZA).

Banks, J., Oldfield, Z., and Wakefield, M. (2002). The distribution of financial wealth in the UK: evidence from 2000 BHPS data. Technical Report WP02/21, Institute for Fiscal Studies.

Benito, A. (2009). Who withdraws housing equity and why? Economica, 76:51-70.

Blundell, R. and Bond, S. (1998). Initial conditions and moment restrictions in dynamic panel data models. Journal of Econometrics, 87:115-143.

Bond, S., Nauges, C., and Windmeijer, F. (2005). Unit roots: identification and testing in micro panels. Cemmap Working Paper CWP07/05. The Institute for Fiscal Studies. University College London.

Bridges, S., Disney, R., and Henley, A. (2006). Housing wealth and the accumulation of financial debt: evidence from uk households. In Bertola, G., Disney, R., and Grant, C., editors, The Economics of Consumer Credit. MIT Press.

Brown, S., Garino, G., Simmons, P., and Taylor, K. (2008). Debt and risk preference: a household level analysis. Sheffield Economic Research Paper Series No. 2008005.

Browning, M., Gortz, M., and Leth-Petersen, S. (2013). Housing wealth and consumption: a micro panel study. The Economic Journal, 123:401-428. 
Buiter, W. H. (2008). Housing wealth isn't wealth. Technical report, National Bureau of Economic Research.

Campbell, J. Y. and Cocco, J. F. (2007). How do house prices affect consumption? Evidence from micro data. Journal of Monetary Economics, 54:591-621.

Canner, G., Dynan, K., and Passmore, W. (2002). Mortgage refinancing in 2001 and early 2002. Federal Reserve Bulletin, 88:469-481.

Carroll, C., Otsuka, M., and Slacalek, J. (2011). How large are housing and financial wealth effects? A new approach. Journal of Money, Credit and Banking, 43:55-79.

Carroll, C. D. (2009). Precautionary saving and the marginal propensity to consume out of permanent income. Journal of monetary Economics, 56(6):780-790.

Case, K., Quigley, J., and Shiller, R. (2005). Comparing wealth effects: the stock market versus the housing market. Adances in Macroeconomics, 5:1-32.

Deaton, A. (1991). Saving and liquidity constraints. Econometrica: Journal of the Econometric Society, pages 1221-1248.

Deaton, A. (1992). Understanding Consumption. Clarendon Press, Oxford.

Disney, R., Bridges, S., and Gathergood, J. (2010a). House price shocks and household indebtedness in the United Kingdom. Economica, 77:472-496.

Disney, R., Gathergood, J., and Henley, A. (2010b). House price shocks, negative equity, and household consumption in the United Kingdom. Journal of the European Economic Association, 8:1179-1207.

Disney, R., Henley, A., and Stears, G. (2002). Housing costs, house price shocks and sav- 
ings behaviour among older households in britain. Regional Science and Urban Economics, $32: 607-625$.

Ebner, A. (2010). A micro view on home equity withdrawal and its determinants. evidence from Dutch households. Munich Discussion Paper No. 2010-2, Department of Economics. University of Munich.

Engelhardt, G. (1996). House prices and home owners saving behaviour. Regional Science and Urban Economics, 26:313-336.

Greene, W. H. (1996). Marginal effects in the bivariate probit model. Working papers, New York University, Leonard N. Stern School of Business, Department of Economics.

Greene, W. H. (1998). Gender economics courses in liberal arts colleges: Further results. The Journal of Economic Education, 29(4):291-300.

Greene, W. H. (2003). Econometric Analysis. Prentice Hall, fifth edition.

Greenspan, A. and Kennedy, J. (2008). Sources and uses of equity extracted from homes. Oxford Review of Economic Policy, 24(1):120-144.

Henderson, J. V. and Ioannides, Y. M. (1983). A model of housing tenure choice. The American Economic Review, pages 98-113.

Hurst, E. and Stafford, F. (2004). Home is where the equity is: mortgage refinancing and household consumption. Journal of Money, Credit ES Banking, 39:985-1014.

Iacoviello, M. (2004). Consumption, house prices, and collateral constraints: a structural econometric analysis. Journal of Housig Economics, 13:304-320.

Meghir, C. and Pistaferri, L. (2004). Income variance dynamics and heterogeneity. Econometrica, $72: 1-32$. 
Pagan, A. R. (1984). Econometric issues in the analysis of regressions with generated regressors. International Economic Review, 25:221-247.

Pistaferri, L. (2001). Superior information, income shocks, and the permanent income hypothesis. The Review of Economics and Statistics, 83:465-476.

Redwood, V. and Tudela, M. (2004). From tiny samples do mighty populations grow? using the british household panel survey to analyse the household sector balance sheet. Bank of England Working Paper no.239.

Windmeijer, F. (2005). A finite sample correction for the variance of linear efficient two-step GMM estimators. Journal of Econometrics, 126:25-51.

Wooldridge, J. M. (2002). Econometric analysis of cross section and panel data. The MIT Press.

\section{A Appendix}

Table 8: Equity withdrawal and family composition

\begin{tabular}{lcc}
\hline \hline Household type & \% withdrawing equity & obs. \\
\hline Single & & \\
no children & 3.88 & 2475 \\
with children & 9.43 & 159 \\
\hline Married/Cohabiting & & \\
no children & 3.24 & 15865 \\
with children & 9.46 & 9811 \\
\hline Divorced/Separated & & \\
no children & 7.81 & 2434 \\
with children & 7.67 & 2346 \\
\hline \hline
\end{tabular}


Table 9: Bivariate probit estimation results - non-mover households

\begin{tabular}{|c|c|c|c|c|c|}
\hline $\begin{array}{l}\text { Dependent variable: } \\
\text { equity withdrawn }\end{array}$ & (1) & $(2)$ & (3) & (4) & $(5)$ \\
\hline$\Delta \ln \left(\pi_{i t}\right)$ & $\begin{array}{c}0.411^{* * *} \\
(0.081)\end{array}$ & & $\begin{array}{c}0.408^{* * *} \\
(0.082)\end{array}$ & & \\
\hline reg. house price volatility ${ }^{a}$ & $\begin{array}{c}1.249^{*} \\
(0.738)\end{array}$ & $\begin{array}{l}-0.085 \\
(0.842)\end{array}$ & $\begin{array}{l}1.380^{*} \\
(0.749)\end{array}$ & $\begin{array}{l}1.348^{*} \\
(0.739)\end{array}$ & \\
\hline reg. house price inflation & & $\begin{array}{c}1.589^{* * *} \\
(0.402)\end{array}$ & & & \\
\hline$\Delta$ financial expectations $^{b}$ & & & $\begin{array}{c}0.072^{* *} \\
(0.029)\end{array}$ & & \\
\hline$E\left(\Delta y_{i t}\right)$ & & & & $\begin{array}{c}0.503^{* * *} \\
(0.153)\end{array}$ & $\begin{array}{c}0.486^{* * *} \\
(0.154)\end{array}$ \\
\hline$\hat{\epsilon}_{i t}^{y}$ & & & & $\begin{array}{c}-0.364^{* *} \\
(0.151)\end{array}$ & $\begin{array}{c}-0.342^{* *} \\
(0.153)\end{array}$ \\
\hline$E\left(\Delta \pi_{i t}\right)$ & & & & $\begin{array}{c}0.217 \\
(0.138)\end{array}$ & $\begin{array}{l}0.251^{*} \\
(0.150)\end{array}$ \\
\hline$\hat{\epsilon}_{i t}^{\pi}$ & & & & $\begin{array}{c}0.449 * * * \\
(0.083)\end{array}$ & $\begin{array}{c}0.459^{* * * *} \\
(0.107)\end{array}$ \\
\hline$\hat{\sigma}_{i t}^{y}$ & & & & & $\begin{array}{l}-0.146^{*} \\
(0.079)\end{array}$ \\
\hline$\hat{\sigma_{r t}^{\pi}}$ & & & & & $\begin{array}{l}-0.050 \\
(0.072)\end{array}$ \\
\hline $\ln \left(y_{i t}\right)$ & $\begin{array}{l}0.073^{*} \\
(0.040)\end{array}$ & $\begin{array}{l}0.072^{*} \\
(0.039)\end{array}$ & $\begin{array}{l}0.074^{*} \\
(0.040)\end{array}$ & $\begin{array}{c}0.444^{* * *} \\
(0.137)\end{array}$ & $\begin{array}{c}0.432^{* * * *} \\
(0.137)\end{array}$ \\
\hline $\ln ($ assets $)$ & $\begin{array}{c}-0.016^{* * *} \\
(0.005)\end{array}$ & $\begin{array}{c}-0.016^{* * *} \\
(0.005)\end{array}$ & $\begin{array}{c}-0.015 * * * \\
(0.005)\end{array}$ & $\begin{array}{c}-0.015^{* * *} \\
(0.005)\end{array}$ & $\begin{array}{c}-0.015^{* * *} \\
(0.005)\end{array}$ \\
\hline $\ln \left(\right.$ mortgage $\left._{i, t-1}\right)$ & $\begin{array}{c}0.126^{* * *} \\
(0.011)\end{array}$ & $\begin{array}{c}0.125^{* * *} \\
(0.011)\end{array}$ & $\begin{array}{c}0.126^{* * *} \\
(0.011)\end{array}$ & $\begin{array}{c}0.127^{* * *} \\
(0.011)\end{array}$ & $\begin{array}{c}0.126^{* * *} \\
(0.011)\end{array}$ \\
\hline endowment mortgage & $\begin{array}{c}0.021 \\
(0.041)\end{array}$ & $\begin{array}{c}0.026 \\
(0.041)\end{array}$ & $\begin{array}{c}0.019 \\
(0.041)\end{array}$ & $\begin{array}{c}0.024 \\
(0.041)\end{array}$ & $\begin{array}{c}0.023 \\
(0.041)\end{array}$ \\
\hline age & $\begin{array}{c}0.001 \\
(0.014)\end{array}$ & $\begin{array}{l}-0.000 \\
(0.014)\end{array}$ & $\begin{array}{c}0.002 \\
(0.014)\end{array}$ & $\begin{array}{l}-0.012 \\
(0.015)\end{array}$ & $\begin{array}{l}-0.011 \\
(0.015)\end{array}$ \\
\hline age squared & $\begin{array}{l}-0.000 \\
(0.000)\end{array}$ & $\begin{array}{l}-0.000 \\
(0.000)\end{array}$ & $\begin{array}{l}-0.000 \\
(0.000)\end{array}$ & $\begin{array}{c}0.000 \\
(0.000)\end{array}$ & $\begin{array}{c}0.000 \\
(0.000)\end{array}$ \\
\hline no. kids & $\begin{array}{c}0.082^{* * *} \\
(0.017)\end{array}$ & $\begin{array}{c}0.084^{* * *} \\
(0.017)\end{array}$ & $\begin{array}{c}0.085^{* * *} \\
(0.017)\end{array}$ & $\begin{array}{c}0.082^{* * *} \\
(0.017)\end{array}$ & $\begin{array}{c}0.082^{* * * *} \\
(0.017)\end{array}$ \\
\hline got married & $\begin{array}{c}0.062 \\
(0.102)\end{array}$ & $\begin{array}{c}0.060 \\
(0.102)\end{array}$ & $\begin{array}{c}0.065 \\
(0.104)\end{array}$ & $\begin{array}{c}0.057 \\
(0.103)\end{array}$ & $\begin{array}{c}0.057 \\
(0.103)\end{array}$ \\
\hline got divorced & $\begin{array}{c}0.596^{* * *} \\
(0.133)\end{array}$ & $\begin{array}{c}0.596^{* * *} \\
(0.133)\end{array}$ & $\begin{array}{c}0.599 * * * \\
(0.133)\end{array}$ & $\begin{array}{c}0.623^{* * *} \\
(0.133)\end{array}$ & $\begin{array}{c}0.636^{* * *} \\
(0.134)\end{array}$ \\
\hline$\Delta$ employed & $\begin{array}{c}-0.050^{*} \\
(0.029)\end{array}$ & $\begin{array}{c}-0.050^{*} \\
(0.029)\end{array}$ & $\begin{array}{l}-0.045 \\
(0.029)\end{array}$ & $\begin{array}{l}-0.015 \\
(0.032)\end{array}$ & $\begin{array}{l}-0.019 \\
(0.032)\end{array}$ \\
\hline
\end{tabular}


Table 9: Bivariate probit estimation results - non-mover households (continued)

\begin{tabular}{|c|c|c|c|c|c|}
\hline $\begin{array}{l}\text { Dependent variable: } \\
\text { saves from current income }\end{array}$ & (1) & $(2)$ & (3) & (4) & $(5)$ \\
\hline$\Delta \ln \left(\pi_{i t}\right)$ & $\begin{array}{c}0.046 \\
(0.036)\end{array}$ & & $\begin{array}{c}0.045 \\
(0.037)\end{array}$ & & \\
\hline reg. house price volatility ${ }^{\mathrm{a}}$ & $\begin{array}{c}0.392 \\
(0.534)\end{array}$ & $\begin{array}{c}0.413 \\
(0.612)\end{array}$ & $\begin{array}{c}0.366 \\
(0.539)\end{array}$ & $\begin{array}{c}0.379 \\
(0.540)\end{array}$ & \\
\hline reg. house price inflation & & $\begin{array}{c}0.015 \\
(0.262)\end{array}$ & & & \\
\hline$\Delta$ financial expectations ${ }^{\mathrm{b}}$ & & & $\begin{array}{l}-0.018 \\
(0.020)\end{array}$ & & \\
\hline$E\left(\Delta y_{i t}\right)$ & & & & $\begin{array}{c}0.067 \\
(0.117)\end{array}$ & $\begin{array}{c}0.014 \\
(0.117)\end{array}$ \\
\hline$\hat{\epsilon}_{i t}^{y}$ & & & & $\begin{array}{c}-0.321^{* * *} \\
(0.116)\end{array}$ & $\begin{array}{c}-0.280^{* *} \\
(0.116)\end{array}$ \\
\hline$E\left(\Delta \pi_{i t}\right)$ & & & & $\begin{array}{c}0.049 \\
(0.091)\end{array}$ & $\begin{array}{c}0.064 \\
(0.088)\end{array}$ \\
\hline$\hat{\epsilon}_{i t}^{\pi}$ & & & & $\begin{array}{c}0.044 \\
(0.039)\end{array}$ & $\begin{array}{c}0.032 \\
(0.041)\end{array}$ \\
\hline$\sigma_{i t}^{y}$ & & & & & $\begin{array}{c}-0.355^{* * *} \\
(0.057)\end{array}$ \\
\hline$\hat{\sigma_{r t}^{\pi}}$ & & & & & $\begin{array}{c}-0.159 * * * \\
(0.037)\end{array}$ \\
\hline $\ln \left(y_{i t}\right)$ & $\begin{array}{c}0.438^{* * *} \\
(0.032)\end{array}$ & $\begin{array}{c}0.439^{* * *} \\
(0.032)\end{array}$ & $\begin{array}{c}0.437^{* * *} \\
(0.033)\end{array}$ & $\begin{array}{c}0.644^{* * *} \\
(0.107)\end{array}$ & $\begin{array}{c}0.623^{* * *} \\
(0.107)\end{array}$ \\
\hline $\ln ($ assets $)$ & $\begin{array}{c}0.071^{* * *} \\
(0.004)\end{array}$ & $\begin{array}{c}0.071^{* * *} \\
(0.004)\end{array}$ & $\begin{array}{l}0.070^{* * *} \\
(0.004)\end{array}$ & $\begin{array}{l}0.071^{* * *} \\
(0.004)\end{array}$ & $\begin{array}{c}0.071^{* * *} \\
(0.004)\end{array}$ \\
\hline $\ln \left(\right.$ mortgage $\left.e_{i, t-1}\right)$ & $\begin{array}{l}-0.001 \\
(0.004)\end{array}$ & $\begin{array}{l}-0.001 \\
(0.004)\end{array}$ & $\begin{array}{l}-0.001 \\
(0.004)\end{array}$ & $\begin{array}{l}-0.002 \\
(0.004)\end{array}$ & $\begin{array}{l}-0.003 \\
(0.004)\end{array}$ \\
\hline$M_{i t}$ & $\begin{array}{c}-1.168 * * * \\
(0.180)\end{array}$ & $\begin{array}{c}-1.115^{* * *} \\
(0.204)\end{array}$ & $\begin{array}{c}-1.163^{* * *} \\
(0.178)\end{array}$ & $\begin{array}{c}-1.130^{* * *} \\
(0.196)\end{array}$ & $\begin{array}{c}-1.116^{* * *} \\
(0.201)\end{array}$ \\
\hline age & $\begin{array}{c}-0.012^{*} \\
(0.007)\end{array}$ & $\begin{array}{c}-0.012^{*} \\
(0.007)\end{array}$ & $\begin{array}{c}-0.011^{*} \\
(0.007)\end{array}$ & $\begin{array}{c}-0.019 * * \\
(0.008)\end{array}$ & $\begin{array}{c}-0.017^{* *} \\
(0.008)\end{array}$ \\
\hline age squared & $\begin{array}{c}0.000 \\
(0.000)\end{array}$ & $\begin{array}{c}0.000 \\
(0.000)\end{array}$ & $\begin{array}{c}0.000 \\
(0.000)\end{array}$ & $\begin{array}{l}0.000^{*} \\
(0.000)\end{array}$ & $\begin{array}{c}0.000 \\
(0.000)\end{array}$ \\
\hline no. kids & $\begin{array}{c}-0.087 * * * \\
(0.017)\end{array}$ & $\begin{array}{c}-0.087^{* * *} \\
(0.018)\end{array}$ & $\begin{array}{c}-0.086^{* * *} \\
(0.018)\end{array}$ & $\begin{array}{c}-0.088^{* * *} * \\
(0.018)\end{array}$ & $\begin{array}{c}-0.091 * * * \\
(0.018)\end{array}$ \\
\hline got married & $\begin{array}{c}0.057 \\
(0.076)\end{array}$ & $\begin{array}{c}0.058 \\
(0.076)\end{array}$ & $\begin{array}{c}0.055 \\
(0.077)\end{array}$ & $\begin{array}{c}0.061 \\
(0.076)\end{array}$ & $\begin{array}{c}0.068 \\
(0.076)\end{array}$ \\
\hline got divorced & $\begin{array}{c}-0.329 * * * \\
(0.101)\end{array}$ & $\begin{array}{c}-0.337^{* * *} \\
(0.102)\end{array}$ & $\begin{array}{c}-0.343^{* * *} \\
(0.102)\end{array}$ & $\begin{array}{c}-0.328^{* * *} \\
(0.102)\end{array}$ & $\begin{array}{c}-0.304^{* * *} \\
(0.103)\end{array}$ \\
\hline$\Delta$ employed & $\begin{array}{c}0.016 \\
(0.017)\end{array}$ & $\begin{array}{c}0.017 \\
(0.017)\end{array}$ & $\begin{array}{c}0.009 \\
(0.017)\end{array}$ & $\begin{array}{c}0.049 * * \\
(0.020)\end{array}$ & $\begin{array}{l}0.039^{*} \\
(0.020)\end{array}$ \\
\hline$\rho^{\mathrm{c}}$ & $\begin{array}{c}0.584^{* * *} \\
(0.123)\end{array}$ & $\begin{array}{c}0.548^{* * *} \\
(0.134)\end{array}$ & $\begin{array}{c}0.580^{* * *} \\
(0.121)\end{array}$ & $\begin{array}{c}0.559^{* * *} \\
(0.130)\end{array}$ & $\begin{array}{c}0.547^{* * *} \\
(0.133)\end{array}$ \\
\hline log-pseudo likelihood & -17037.131 & -17043.781 & -16527.428 & -17017.609 & -16968.779 \\
\hline households/observations & $5247 / 21796$ & $5247 / 21796$ & $5193 / 21157$ & $5247 / 21796$ & $5247 / 21796$ \\
\hline
\end{tabular}

Coefficient estimates are reported, not marginal effects. Cluster-robust standard errors in parentheses. $* * *, * *$ and $*$ denote significance at the $1 \%, 5 \%$ and $10 \%$ level respectively. Year, education and employment dummies were included in all estimations. $\quad{ }^{a}$ This measure of house price volatility is calculated as the standard deviation of the change in the log real house price over previous five years for each region using Halifax house price data, as in Banks et al. (2010). b This refers to the subjective financial expectations variable, which captures the change in household expectations, measured on a three-point scale $(1=$ improved, $0=$ no change, $-1=$ worsened $)$.

${ }^{\mathrm{c}}$ Measure of conditional correlation between the dependent variables. 
Table 10: Estimation results by age group - bivariate probit model

\begin{tabular}{|c|c|c|c|c|}
\hline Dependent variable: equity withdrawn & $\begin{array}{l}30-50 \mathrm{~A} \\
(1)\end{array}$ & $\begin{array}{r}\text { group } \\
(2)\end{array}$ & $\begin{array}{l}50+\mathrm{A} \\
(3)\end{array}$ & $\begin{array}{l}\text { group } \\
(4)\end{array}$ \\
\hline$\Delta \ln \left(\pi_{i t}\right)$ & $\begin{array}{c}0.263^{* * *} \\
(0.075)\end{array}$ & & $\begin{array}{c}0.070 \\
(0.182)\end{array}$ & \\
\hline reg. house price volatility ${ }^{\mathrm{a}}$ & $\begin{array}{l}1.683^{* *} \\
(0.815)\end{array}$ & & $\begin{array}{c}1.134 \\
(1.687)\end{array}$ & \\
\hline$E\left(\Delta y_{i t}\right)$ & & $\begin{array}{c}0.590^{* * *} \\
(0.174)\end{array}$ & & $\begin{array}{c}0.498 \\
(0.315)\end{array}$ \\
\hline$\hat{\epsilon}_{i t}^{y}$ & & $\begin{array}{c}-0.385^{* *} \\
(0.168)\end{array}$ & & $\begin{array}{l}0.005 \\
(0.305)\end{array}$ \\
\hline$E\left(\Delta \pi_{i t}\right)$ & & $\begin{array}{c}0.386^{* *} \\
(0.182)\end{array}$ & & $\begin{array}{l}-0.099 \\
(0.234)\end{array}$ \\
\hline$\hat{\epsilon}_{i t}^{\pi}$ & & $\begin{array}{c}0.477^{* * *} \\
(0.139)\end{array}$ & & $\begin{array}{c}0.096 \\
(0.126)\end{array}$ \\
\hline$\hat{\sigma}_{i t}^{y}$ & & $\begin{array}{l}-0.146 \\
(0.092)\end{array}$ & & $\begin{array}{c}-0.443^{* *} \\
(0.206)\end{array}$ \\
\hline$\sigma_{r t}^{\hat{\pi}}$ & & $\begin{array}{c}-0.126^{*} \\
(0.075)\end{array}$ & & $\begin{array}{c}0.072^{* *} \\
(0.036)\end{array}$ \\
\hline $\ln \left(y_{i t}\right)$ & $\begin{array}{c}0.042 \\
(0.043)\end{array}$ & $\begin{array}{c}0.469 * * * \\
(0.155)\end{array}$ & $\begin{array}{c}0.188^{* *} \\
(0.077)\end{array}$ & $\begin{array}{c}0.397 \\
(0.259)\end{array}$ \\
\hline $\ln ($ assets $)$ & $\begin{array}{c}-0.014 * * * \\
(0.005)\end{array}$ & $\begin{array}{c}-0.013^{* *} \\
(0.005)\end{array}$ & $\begin{array}{l}-0.014 \\
(0.010)\end{array}$ & $\begin{array}{l}-0.015 \\
(0.010)\end{array}$ \\
\hline $\ln \left(\right.$ mortgage $\left._{i, t-1}\right)$ & $\begin{array}{c}0.096^{* * *} \\
(0.011)\end{array}$ & $\begin{array}{c}0.096^{* * *} * \\
(0.012)\end{array}$ & $\begin{array}{c}0.129 * * * \\
(0.015)\end{array}$ & $\begin{array}{c}0.128^{* * *} * \\
(0.016)\end{array}$ \\
\hline endowment mortgage & $\begin{array}{c}0.031 \\
(0.047)\end{array}$ & $\begin{array}{c}0.029 \\
(0.047)\end{array}$ & $\begin{array}{c}0.141 \\
(0.092)\end{array}$ & $\begin{array}{c}0.138 \\
(0.092)\end{array}$ \\
\hline moved $_{i t}$ & $\begin{array}{c}-0.359 * * * \\
(0.086)\end{array}$ & $\begin{array}{c}-0.391^{* * *} \\
(0.088)\end{array}$ & $\begin{array}{c}-0.523^{* *} \\
(0.221)\end{array}$ & $\begin{array}{c}-0.516^{* *} \\
(0.224)\end{array}$ \\
\hline age & $\begin{array}{c}-0.046 \\
(0.052)\end{array}$ & $\begin{array}{l}-0.050 \\
(0.052)\end{array}$ & $\begin{array}{c}-0.147^{* *} \\
(0.061)\end{array}$ & $\begin{array}{c}-0.147^{* *} \\
(0.061)\end{array}$ \\
\hline age squared & $\begin{array}{c}0.001 \\
(0.001)\end{array}$ & $\begin{array}{c}0.001 \\
(0.001)\end{array}$ & $\begin{array}{c}0.001^{* *} \\
(0.000)\end{array}$ & $\begin{array}{c}0.001^{* *} \\
(0.000)\end{array}$ \\
\hline no. kids & $\begin{array}{c}0.071^{* * *} * \\
(0.018)\end{array}$ & $\begin{array}{c}0.067^{* * *} * \\
(0.018)\end{array}$ & $\begin{array}{l}-0.001 \\
(0.083)\end{array}$ & $\begin{array}{l}-0.002 \\
(0.087)\end{array}$ \\
\hline got married & $\begin{array}{c}0.137 \\
(0.112)\end{array}$ & $\begin{array}{c}0.126 \\
(0.112)\end{array}$ & $\begin{array}{l}-0.147 \\
(0.418)\end{array}$ & $\begin{array}{l}-0.106 \\
(0.399)\end{array}$ \\
\hline got divorced & $\begin{array}{c}0.447^{* * *} * \\
(0.130)\end{array}$ & $\begin{array}{c}0.496^{* * *} \\
(0.131)\end{array}$ & $\begin{array}{c}0.735^{* * *} \\
(0.260)\end{array}$ & $\begin{array}{c}0.719^{* * *} \\
(0.257)\end{array}$ \\
\hline$\Delta$ employed & $\begin{array}{l}-0.019 \\
(0.032)\end{array}$ & $\begin{array}{c}0.013 \\
(0.035)\end{array}$ & $\begin{array}{c}-0.074 \\
(0.065)\end{array}$ & $\begin{array}{l}-0.082 \\
(0.077)\end{array}$ \\
\hline
\end{tabular}


Table 10: Estimation results by age group - bivariate probit model (continued)

\begin{tabular}{|c|c|c|c|c|}
\hline \multirow{3}{*}{ Dependent variable: saves from current income } & \multicolumn{2}{|c|}{ 30-50 Age group } & \multicolumn{2}{|c|}{$50+$ Age group } \\
\hline & (1) & $(2)$ & $(3)$ & $(4)$ \\
\hline & & & & \\
\hline \multirow{2}{*}{$\Delta \ln \left(\pi_{i t}\right)$} & -0.004 & & 0.011 & \\
\hline & $(0.034)$ & & $(0.043)$ & \\
\hline \multirow[t]{2}{*}{ reg. house price volatility ${ }^{\mathrm{a}}$} & 0.875 & & -0.003 & \\
\hline & $(0.752)$ & & $(0.754)$ & \\
\hline \multirow[t]{2}{*}{$E\left(\Delta y_{i t}\right)$} & & $0.267^{*}$ & & -0.046 \\
\hline & & $(0.159)$ & & $(0.162)$ \\
\hline \multirow{2}{*}{$\hat{\epsilon}_{i t}^{y}$} & & $-0.344^{* *}$ & & -0.260 \\
\hline & & $(0.154)$ & & $(0.163)$ \\
\hline \multirow[t]{2}{*}{$E\left(\Delta \pi_{i t}\right)$} & & -0.017 & & 0.082 \\
\hline & & $(0.113)$ & & $(0.123)$ \\
\hline \multirow[t]{2}{*}{$\hat{\epsilon}_{i t}^{\pi}$} & & 0.017 & & -0.017 \\
\hline & & $(0.052)$ & & $(0.054)$ \\
\hline \multirow[t]{2}{*}{$\sigma_{i t}^{\hat{y}}$} & & $-0.389 * * *$ & & $-0.266^{* * *}$ \\
\hline & & $(0.077)$ & & $(0.074)$ \\
\hline \multirow{2}{*}{$\sigma_{r t}^{\hat{\pi}}$} & & $-0.072^{* *}$ & & $-0.224^{* * *}$ \\
\hline & & $(0.029)$ & & $(0.059)$ \\
\hline \multirow[t]{2}{*}{$\ln \left(y_{i t}\right)$} & $0.468^{* * *}$ & $0.767 * * *$ & $0.380^{* * *}$ & $0.544 * * *$ \\
\hline & $(0.044)$ & $(0.144)$ & $(0.045)$ & $(0.149)$ \\
\hline \multirow[t]{2}{*}{$\ln ($ assets $)$} & $0.089 * * *$ & $0.089 * * *$ & $0.060^{* * *}$ & $0.059 * * *$ \\
\hline & $(0.005)$ & $(0.005)$ & $(0.005)$ & $(0.005)$ \\
\hline \multirow[t]{2}{*}{$\ln \left(\right.$ mortgage $\left._{i, t-1}\right)$} & -0.002 & -0.005 & 0.001 & -0.000 \\
\hline & $(0.007)$ & $(0.007)$ & $(0.005)$ & $(0.005)$ \\
\hline \multirow[t]{2}{*}{$M_{i t}$} & $-0.797^{* *}$ & $-0.759^{* *}$ & $-1.301 * * *$ & $-1.402^{* * *}$ \\
\hline & $(0.317)$ & $(0.333)$ & $(0.484)$ & $(0.459)$ \\
\hline \multirow[t]{2}{*}{ moved $_{i t}$} & $-0.182^{* * *}$ & $-0.154^{* * *}$ & $-0.290^{* * *}$ & $-0.238^{* * *}$ \\
\hline & $(0.053)$ & $(0.054)$ & $(0.073)$ & $(0.074)$ \\
\hline \multirow[t]{2}{*}{ age } & 0.073 & 0.072 & -0.034 & -0.030 \\
\hline & $(0.045)$ & $(0.045)$ & $(0.031)$ & $(0.031)$ \\
\hline \multirow[t]{2}{*}{ age squared } & $-0.001^{* *}$ & $-0.001^{* *}$ & 0.000 & 0.000 \\
\hline & $(0.001)$ & $(0.001)$ & $(0.000)$ & $(0.000)$ \\
\hline \multirow[t]{2}{*}{ no. kids } & $-0.090^{* * *}$ & $-0.095^{* * *}$ & $-0.207^{* * *}$ & $-0.209 * * *$ \\
\hline & $(0.019)$ & $(0.020)$ & $(0.055)$ & $(0.055)$ \\
\hline \multirow[t]{2}{*}{ got married } & 0.102 & 0.110 & -0.282 & -0.271 \\
\hline & $(0.087)$ & $(0.087)$ & $(0.176)$ & $(0.179)$ \\
\hline \multirow[t]{2}{*}{ got divorced } & $-0.258^{* *}$ & $-0.225^{*}$ & $-0.666^{* * *}$ & $-0.597 * * *$ \\
\hline & $(0.116)$ & $(0.119)$ & $(0.172)$ & $(0.174)$ \\
\hline \multirow[t]{2}{*}{$\Delta$ employed } & 0.021 & $0.051^{* *}$ & 0.014 & 0.036 \\
\hline & $(0.022)$ & $(0.026)$ & $(0.023)$ & $(0.029)$ \\
\hline \multirow[t]{2}{*}{$\rho^{\mathrm{C}}$} & $0.356^{* *}$ & $0.331^{*}$ & $0.600^{* *}$ & $0.675^{* *}$ \\
\hline & $(0.179)$ & $(0.186)$ & $(0.304)$ & $(0.317)$ \\
\hline \multirow{2}{*}{$\begin{array}{l}\text { log-pseudo likelihood } \\
\text { observations }\end{array}$} & -10071.588 & -10029.53 & -7562.884 & -7521.105 \\
\hline & 3 090/ 11724 & 3 090/ 11724 & $2528 / 10981$ & $2528 / 10981$ \\
\hline
\end{tabular}

Coefficient estimates are reported, not marginal effects. Cluster-robust standard errors in parentheses. $* * *$, ** and $*$ denote significance at the $1 \%, 5 \%$ and $10 \%$ level respectively. Year, education and employment dummies were included in all estimations. a This measure of house price volatility is calculated as the standard deviation of the change in the log real house price over previous five years for each region using Halifax house price data, as in Banks et al. (2010). $\mathrm{b}$ This refers to the subjective financial expectations variable, which captures the change in household expectations, measured on a three-point scale $(1=$ improved, $0=$ no change, $-1=$ worsened).

${ }^{\mathrm{c}}$ Measure of conditional correlation between the dependent variables. 